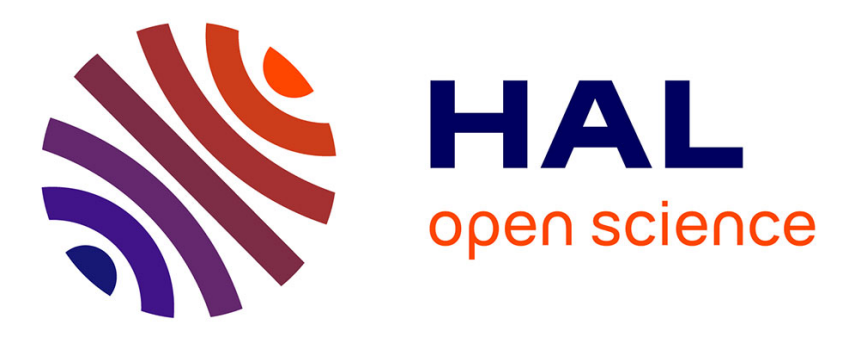

\title{
Influence of infrastructure material composition and microtopography on marine biofilm growth and photobiology
}

Baptiste Vivier, Pascal Claquin, Christophe Lelong, Quentin Lesage, Mathias Peccate, Bastien Hamel, Marine Georges, Amel Bourguiba, Nassim Sebaibi, Mohamed Boutouil, et al.

\section{To cite this version:}

Baptiste Vivier, Pascal Claquin, Christophe Lelong, Quentin Lesage, Mathias Peccate, et al.. Influence of infrastructure material composition and microtopography on marine biofilm growth and photobiology. Biofouling, 2021, 37 (7), pp.740-756. 10.1080/08927014.2021.1959918 . hal-03320902

\section{HAL Id: hal-03320902 https://hal.science/hal-03320902}

Submitted on 16 Aug 2021

HAL is a multi-disciplinary open access archive for the deposit and dissemination of scientific research documents, whether they are published or not. The documents may come from teaching and research institutions in France or abroad, or from public or private research centers.
L'archive ouverte pluridisciplinaire HAL, est destinée au dépôt et à la diffusion de documents scientifiques de niveau recherche, publiés ou non, émanant des établissements d'enseignement et de recherche français ou étrangers, des laboratoires publics ou privés. 


\section{Influence of infrastructure material composition and microtopography on marine biofilm growth and photobiology}

Baptiste Vivier, Pascal Claquin, Christophe Lelong, Quentin Lesage, Mathias Peccate, Bastien Hamel, Marine Georges, Amel Bourguiba, Nassim Sebaibi, Mohamed Boutouil, Didier Goux, JeanClaude Dauvin, and Francis Orvain

\section{QUERY SHEET}

This page lists questions we have about your paper. The numbers displayed at left are hyperlinked to the location of the query in your paper.

The title and author names are listed on this sheet as they will be published, both on your paper and on the Table of Contents. Please review and ensure the information is correct and advise us if any changes need to be made. In addition, please review your paper as a whole for typographical and essential corrections.

Your PDF proof has been enabled so that you can comment on the proof directly using Adobe Acrobat. For further information on marking corrections using Acrobat, please visit http://journalauthors.tandf.co.uk/production/acrobat.asp; https://authorservices.taylorandfrancis.com/how-to-correct-proofs-with-adobe/

The CrossRef database (www.crossref.org/) has been used to validate the references.

\section{AUTHOR QUERIES}

Q1 Please confirm that the affiliations and corresponding author details are OK as typeset.

Q2 Please check that the hierarchy of ALL section heads and subheads in the manuscript are correct.

Q3 Please provide the volume number.

Q4 Please provide the volume number.

Q5 Please note that the ORCID section has been created from information supplied with your manuscript submission/CATS. Please correct if this is inaccurate. 


\title{
Influence of infrastructure material composition and microtopography on marine biofilm growth and photobiology
}

\author{
Baptiste Vivier ${ }^{a, b}$, Pascal Claquin ${ }^{a, b}$, Christophe Lelong $^{a}$, Quentin Lesage ${ }^{a}$, Mathias Peccate ${ }^{a}$, Bastien \\ Q5 Hamel $^{a}$, Marine Georges ${ }^{c}$, Amel Bourguiba ${ }^{c}$, Nassim Sebaibi ${ }^{c}$, Mohamed Boutouil ${ }^{c}$ (D), Didier Goux ${ }^{d}$, Jean- \\ Claude Dauvin ${ }^{\mathrm{e}}$ and Francis Orvain ${ }^{\mathrm{a}, \mathrm{b}}$
}

\begin{abstract}
${ }^{a}$ Normandie Université, Université de Caen Normandie, Caen, France; ${ }^{b}$ Laboratoire Biologie des ORganismes et Ecosystèmes Aquatiques (BOREA, UMR CNRS 8067), Muséum National d'Histoire Naturelle, Sorbonne Université, Université de Caen Normandie, IRD 207, Université des Antilles. Centre de Recherches en Environnement Côtier (CREC) - Station Marine, Caen, France; 'Ecole Supérieure d'Ingénieurs des Travaux de la Construction de Caen (ESITC Caen), Epron, France; ${ }^{d}$ Centre de Microscopie Appliquée à la Biologie, SF 4206 Interaction Cellule-Organisme-Environnement (ICORE), UNICAEN; and CRISMAT, Normandie Univ, ENSICAEN, UNICAEN, CNRS, CRISMAT, Caen, France; 'Laboratoire Morphodynamique Continentale et Côtière, UMR CNRS 6143 M2C, Normandie Université, Université de Caen Normandie, UNIROUEN, Caen, France

\section{ABSTRACT}

The impact of concrete composition and roughness on the formation of microalgal biofilms and their photobiology were studied on marine infrastructures presenting four different compositions combined with two degrees of roughness (rough and smooth). The structures were first inoculated with a natural microphytobenthic biofilm and immersed in sterilised seawater with a controlled photoperiod for six days. Photosynthetic activity was assessed with an imaging PAM(Pulse Amplitude Modulated) fluorometer and microtopography was monitored in parallel with a 3-D camera. The results indicated that roughness had an impact on the biofilm biomass, its physiological status and its photosynthetic efficiency and capacity. The assessment of surface roughness indicated that negative reliefs were preferably colonised by MPB (microphytobenthos) cells with better photosynthetic performances. Moreover, MPB biofilms showed better photoacclimation in these microhabitats than on the positive and smooth reliefs. This study confirms the importance of microhabitat for biofilm formation and their photobiology.
\end{abstract}

ARTICLE HISTORY

Received 2 February 2021

Accepted 19 July 2021

KEYWORDS

Biofilm; hard substrata; rugosity; photosynthesis; PAM fluorometry; biomaterial

\section{Q2 Introduction}

Artificial structures or Artificial Reefs (AR) have been used for decades to attract fish or to protect shallow coastal zones from trawling (Jensen et al. 2000), and their development has intensified over the three last decades (Vivier et al. 2021). Such structures are also favourable areas for biodiversity as they act as settlement zones and nurseries for many marine species (Patranella et al. 2017) by providing a novel habitat and supporting the primary production of organic carbon and its transfer through the trophic network (Charbonnel et al. 2002; Langhamer and Wilhelmsson 2009; Layman et al. 2016; Komyakova and Swearer 2018; Komyakova et al. 2019).

In aquatic environments, surfaces are rapidly colonised by microorganisms (Bakker et al. 2003; Bhosle et al. 2005). Microphytobenthic biofilms $(\mathrm{MPB}(\mathrm{s}))$ are characterised by the assemblage of photosynthetic microalgae (mostly diatoms), cyanobacteria, protozoa and macrophyte spores which form a biofilm on soft sediment or hard substratum surfaces (Kromkamp et al. 1995; Nagarkar et al. 2004). MPB is one of the most important carbon sources for benthic and pelagic trophic webs on intertidal rocky shores (Bulleri 2005). MPB is also a pioneer assemblage in the succession of benthic communities and facilitates the settlement of macroalgae and invertebrates (Huang and Boney 1984; Hung et al. 2007). Biofilms vary in space and over time; they are regulated by environmental and biological parameters like nutrient availability and top-down herbivory control by grazers (Underwood 1984; Hillebrand et al. 2000; Jenkins et al. 2001; Thompson et al. 2004, 2005). Thus, colonisation of hard substrata by MPB is a crucial step for the following ecological succession of new hard substrata in marine environments. The photo-biological features of these biofilms may be

Q1 CONTACT Francis Orvain francis.orvain@unicaen.fr

(7) Supplemental data for this article is available online at https://doi.org/10.1080/08927014.2021.1959918.

(C) 2021 Informa UK Limited, trading as Taylor \& Francis Group 
cues that drive subsequent colonisation stages by mediating the bio-adhesion of planktonic metazoan larvae during settlement (Olivier et al. 2000; Tamburri et al. 2008; Hladyz et al. 2011; Whalan and Webster 2014; Ly et al. 2020).

Reflecting the ecological importance of biofilms in marine environments, their colonisation mechanisms and drivers have been widely studied (Huang and Boney 1984; Hutchinson et al. 2006; Briand et al. 2012; 2017) on soft substrata (Jesus et al. 2006; Orvain et al. 2012; Morelle et al. 2021) or hard substrata (Anderson 1995; Bulleri 2005; Leite et al. 2012). However, only a few authors have investigated the impact of micro-topography, roughness, on biofilm adhesion and colonisation (Chung et al. 2007; Doghri et al. 2015) in marine ecosystems even though these aspects have been widely explored in medical sciences (Oh et al. 2009; Perera-Costa et al. 2014). Marine biofilms are likely to be affected by the microstructure of the substratum and its degree of roughness (Salta et al. 2013; Souche et al. 2016), and it appears that MPB do not colonise such substrata homogeneously (Anderson and Underwood 1994; Hutchinson et al. 2006; Salta et al. 2013). Their complex micro-topography creates a wide range of microenvironments, mainly exposure to light, but also nutrient availability. In small crevices on the surface of the reef, microalgae can find refuge from desiccation and light overexposure which could impair DNA, or cell membrane or protein integrity (Sekar et al. 2004; Perera-Costa et al. 2014). The addition of marine co-produces like shells can also increase substratum porosity and enhance its bio-receptivity (Cuadrado-Rica et al. 2016).

The deployment and management of hard substrata has recently become more important in the current ecological and societal context with the development of immerged marine structures for the purpose of ecological involvement by the creation of novel habitats with expected economic benefits (i.e. the construction of offshore wind farms, seawalls and dikes). Such structures offer innovative solutions with the use of novel materials that increase both their quantitative and qualitative colonisation. The development of marine resources can be promoted by adding coproducts like fragments of oyster shells, which are considered as marine production waste. Shell fragments can also be considered as natural long-term carbon storage that can be exploited to mitigate climate change (Lejart 2009). This study investigated several photosynthetic indicators of MPB biofilms and how biomass developed on different structures. To this end, marine infrastructures (MI) were built to assess the importance of the composition and roughness of the concrete in MPB colonisation and primary productivity.

\section{Materials and methods}

\section{Experimental setup}

A total of $50 \mathrm{MI}$ samples were constructed. The MI were shaped like a cobble $(5 \mathrm{~cm} \times 5 \mathrm{~cm} \times 3 \mathrm{~cm} ; \mathrm{L} \times \times \mathrm{h})$ and for this study, four concrete formulations were designed with two types of cement, Portland cement, CEM I/A-LL 42.5 R CE PM-CP2 NF and CEM II/A (S-V) $32.5 \mathrm{~N}-\mathrm{LH}$ CE PM-ES-CP1 NF as these two types of cement are suitable for use in seawater. Granular class $0 / 2 \mathrm{~mm}$ siliceous alluvial sand was used. Alluvial aggregates of two sizes, $4 / 10 \mathrm{~mm}$ and $10 / 20 \mathrm{~mm}$, were also used. Twenty percent of the aggregates $(4 / 10 \mathrm{~mm})$ were replaced by oyster shell aggregates to study the effect of this biomineral byproduct on the recruitment of oyster larvae. It has been shown that the incorporation of mollusc shell aggregates $(6 / 12.5 \mathrm{~mm})$ could increase the bio-receptivity of concrete because they provide an ideal substratum for the settlement of marine organisms (Graham et al. 2017; Hanlon et al. 2018). Six control samples were made of PVC, as this type of support is suitable and is generally used for oyster larval catchers in shellfish aquaculture.

The absolute density [NF EN 1097-6:2014-01], granular compactness [NF EN 932-2:1999-08 (NF EN 932-2 1999)] and water absorption coefficient [NF EN 1097-6:2014-01] of the different materials were determined. After the characterisation of the raw materials concrete mixes were formulated in accordance with NF EN 206-1 (NF EN 206-1 2016). Table 1 lists the four concrete formulations tested (type 1 to type 4). Each formulation was composed of the cement I (CEM I) or cement II (CEM II) and of the addition or not of oyster shells. In this study, the control structures were polyvinyl chloride (PVC) structures and corresponded to type 5 .

These MI had two different surfaces: one rough and one smooth. The mean gross surface rugosity $\left(\mathrm{R}_{\mathrm{g}}\right)$ was calculated as the mean of the difference between the five higher and lower points of the structure. The mean $\mathrm{R}_{\mathrm{g}}$ by structure type was: $6.19 \mathrm{~mm}$ for the rough ones, $2.72 \mathrm{~mm}$ for the smooth ones and $1.08 \mathrm{~mm}$ for the PVC controls. Each structure was exposed in sterile seawater for one week in order to condition the concrete. Sterilisation was achieved with UV treatment (JBL AquaCristal UV-C $36 \mathrm{~W}$ ) for $48 \mathrm{~h}$ 
Table 1. Concrete type formulation details.

Formulations

\begin{tabular}{lrrrr} 
& Components & Type 1: CEM I no shells & Type 2: CEM I with 20\% shells Type 3: CEM II no shells & Type 4: CEM II with 20\% shells Type 5: PVC controls \\
\hline Cement & 350 & 350 & 350 & 350 \\
Sand & 800 & 800 & 800 & 800 \\
Gravel 4/10 & 600 & 479 & 600 & 479 \\
Gravel 10/20 & 500 & 500 & 500 & 500 \\
Shell aggregates & 121 & 175 & 121 \\
Water & 175 & 175 & 4.5 & 7 \\
Superplasticiser & 4.5 & 7 & &
\end{tabular}

Footnote to Table 1: The four different concrete types (1 to 4) were composed of two different cements (CEM I or II) and the addition or not of $20 \%$ oyster shells.

(Figure 1). Then, the vertical sides of each MI were paraffined to prevent their colonisation from the external borders. Twenty microcosms $(16.2 \mathrm{~cm} \times 11.2 \mathrm{~cm} \times 11.7 \mathrm{~cm} ; \mathrm{L} \times \times \mathrm{h})$ were created to optimise the environmental conditions and promote microphytobenthic development. The internal walls of each microcosm were also covered with paraffin to prevent any interaction between the MI during the experiment. The MI were placed in several microcosm by three and all microcosms were disposed in a mesocosm (650 l) with sterilised sea water and alimented with a circulation pump $\left(300 \mathrm{l} \mathrm{h}^{-1}\right)$. Air was bubbled in each microcosm. All microcosms were entirely immersed at the same level in the mesocosm.

\section{Experimental monitoring}

Several parameters and indicators were measured over a period of six days after the addition of biofilms. Temperature and $\mathrm{pH}$ were recorded throughout the experiment. The distance between the LED and the MI was $60 \mathrm{~cm}$. Light intensities were recorded continuously (i.e. at $1 \mathrm{~min}$ intervals) using Onset Hobo UA-002 Pendant light/temperature ${ }^{\circledR}$ data logger placed on specified cores in the tank.

Microphytobenthic biofilms were taken from natural sea samples in tanks with running seawater pumped from the shore in front of the marine station of the University of Caen (CREC) which is located in the Bay of Seine (French-English Channel). Several large MI built with the same material as the sample MI used for this experiment were placed in these large tanks. Dense microphytobenthic biofilms were obtained on these large MI after incubation for two weeks with running seawater. MPB biofilm were sampled gently on the large MI with a toothbrush then, biofilms were diluted in 11 of seawater. Then, this stock solution containing resuspended biofilms was added in the sterile mesocosm one week after the setup of MI in each microcosm.

\section{Scanning electron microscope observations}

Scanning electron microscope (SEM) observations were performed at the end of the monitoring period. MPB biofilm was carefully sampled from a rough MI with a soft toothbrush at the end of the experiment. The sample was fixed overnight with glutaraldehyde $2.5 \%$ in a buffer of sodium cacodylate $(0.2 \mathrm{M})$ with $7 \%$ of saccharide during sedimentation on Thermanox ${ }^{\mathrm{TM}}$ strips. The samples were then rinsed in this buffer and dehydrated in progressive ethanol baths. Finally, the samples were dried using the critical point bypass method with CPD 030 LEICA $^{\circledR}$. Samples were metalized with platinum with JFC 1200 $\mathrm{JEOL}^{\circledR}$. Observations were made with the SEM Supra 55 ZEISS $^{\circledR}$.

\section{Photosynthetic parameters}

Photosynthetic parameters were measured daily using the Imaging-PAM fluorometer (Walz, Germany). The IMAGING-PAM Chlorophyll Fluorometer was designed to investigate the two-dimensional heterogeneities of photosynthetic activity. Fluorescence measurements were carried out using the Maxi Version of Imaging-PAM Chlorophyll Fluorometer (Walz, Effeltrich, Germany) associated with a LED-Array Illumination Unit IMAG-MAX/L (44 high-power royal-blue $(450 \mathrm{~nm})$ LED-lamps) and a CCD Camera IMAG- K7 equipped with a zoom objective lens (640 $\times 480$ pixel resolution). Measurements were performed at a fixed working distance of $18.5 \mathrm{~cm}$. A 5min dark adaptation period allowed oxidation of the electron acceptor pools before each measurement. The saturation pulse intensity was $4,500 \mu \mathrm{mol}$ photons $\mathrm{m}^{-2} \mathrm{~s}^{-1}$ for $0.8 \mathrm{~s}$ at the surface of the sample and the measuring pulse frequency was $8 \mathrm{~Hz}$. Rapid light curves were performed as follows: samples were exposed to eight incremental intensities of actinic light (E): 0, 21, 111, 281, 396, 531, 611 and $701 \mu \mathrm{mol}$ photons $\mathrm{m}^{-2} \mathrm{~s}^{-1}$ with $30 \mathrm{~s}$ irradiance steps. Numerical values and fluorescence images were extracted using analytical software (Imaging Win; Walz). Auto-fluorescence of each structure was 
319

320

321

322

323

324

325

326

327

328

329

330

331

332

333

334

335

336

337

338

339

340

341

342

343

344

345

346

347

348

349

350

351

352

353

354

355

356

357

358

359

360

361

362

363

364

365

366

367

368

369

COLOR
Online I
$B \& W$ in

$\underset{\text { Print }}{\text { B\&W in }}$
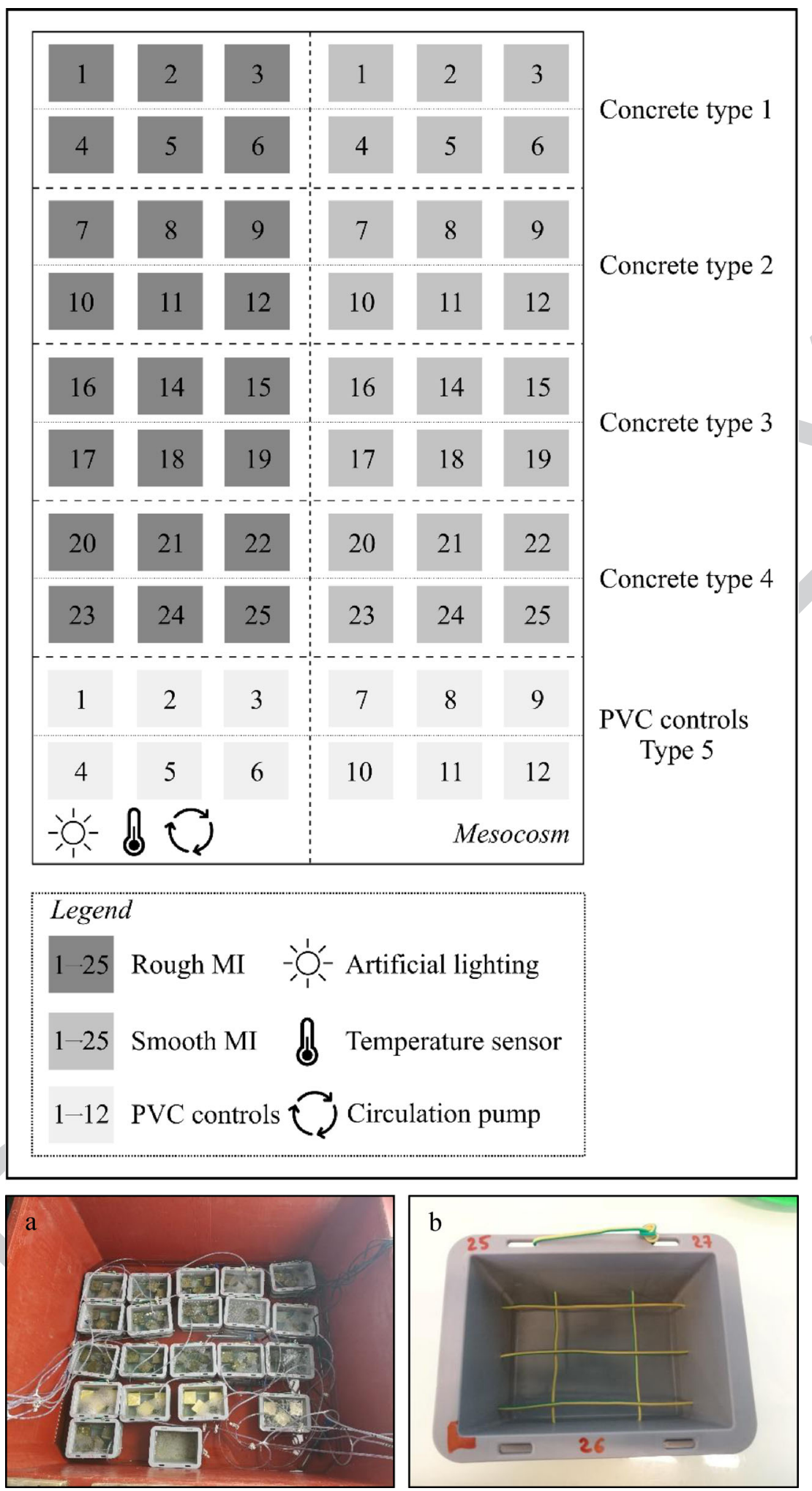

Figure 1. Experimental setup design. Marine infrastructures were placed in threes in 20 microcosms (separated by the dashed lines) placed in a large mesocosm (Image a). Microcosms (Image b) were randomly disposed in the mesocosm to guarantee the total independence between sampled units. Artificial lightning and a circulation pump $\left(300 \mathrm{I} \mathrm{h}^{-1}\right)$ were added for the entire mesocosm. Air bubbling were added in each microcosm. All microcosms were entirely immersed at the same level in the mesocosm. The average light was $113.83 \mu \mathrm{mol}$ photons $\mathrm{m}^{-2} \mathrm{~s}^{-1}$ for $8 \mathrm{~h}$ (from $8 \mathrm{am}$ to $4 \mathrm{pm}$ ) and the average temperature was $20^{\circ} \mathrm{C}$. 
recorded before the experiment in order to apply a correction to $\mathrm{F}_{\mathrm{O}}$.

The maximum quantum efficiency of PSII $\left(\mathrm{F}_{\mathrm{V}} / \mathrm{F}_{\mathrm{M}}\right)$ was calculated using the following equation from Genty et al. (1989):

$$
\frac{F_{V}}{F_{M}}=\frac{\left(F_{M}-F_{0}\right)}{F_{M}}
$$

where $F_{M}$ is the maximum fluorescence yield measured after a saturating pulse and $\mathrm{F}_{0}$ the minimum fluorescence yield immediately before the saturating pulse.

The maximum relative electron transport rate ( rETR $_{\text {MAX, }}$, relative units) was estimated by fitting FLC data with the Webb model (Webb et al. 1974) to estimate $\alpha$ ( $\mu$ mol electrons ( $\mu \mathrm{mol}$ photons) ${ }^{-1}$ and $\mathrm{Ek}$ ( $\mu \mathrm{mol}$ photons $\mathrm{m}^{-2} \mathrm{~s}^{-1}$ ) with $\alpha$ the initial slope of the FLC and Ek the light saturation index:

$$
r E T R=\alpha \times \mathrm{Ek} \times\left(1-e^{-\frac{E}{E k}}\right)
$$

$r \mathrm{ETR}_{\mathrm{MAX}}$ was then calculated as:

$$
r E T R_{M A X}=\alpha_{w e b b} \times E k_{w e b b}
$$

The other option was the Eilers and Peeters (1988) model with $a, b$ and $c$ the equation coefficients to calculate the $\mathrm{rETR}_{\mathrm{MAX}}$ and the photosynthetic efficiency $(\alpha)$.

$$
r E T R=\frac{E}{\left(a E^{2}+b E+c\right)}
$$

or,

$$
r E T R_{M A X}=\frac{1}{(b+2 \sqrt{a c})}
$$

$\alpha$ was calculated as:

$$
\alpha=\frac{1}{c}
$$

Finally, non-photochemical quenching (NPQ) based on the relative difference between the maximum fluorescence measured in the dark-adapted state, $F_{M}$, and upon exposure to light, $F_{M}$ ' was calculated:

$$
N P Q=\frac{F_{M}-F_{M^{\prime}}}{F_{M^{\prime}}}
$$

To estimate photosynthetic $\alpha$ and rETR $_{\text {MAX }}$ for each pixel of the fluorescence image, a nonlinear regression model was fitted on RLC curves using the simplex method of Nelder and Mead (1965). According to the curve profile, the algorithm automatically chose the fitting model between that of Webb et al. (1974) and Eilers and Peeters (1988). In the exceptional case where $\mathrm{rETR}_{\mathrm{MAX}}$ was much higher than the highest rETR, a linear model was applied and the highest rETR was considered as rETR $_{\text {MAX }}$ to avoid overestimation. In the case where (1) the first value (i.e. first E) was the highest in the RLC, (2) RLC values were all equal to zero and (3) the set comprised no more than three positive values, the photosynthetic parameters were considered null.

3-D camera acquisitions. A 3-D camera was used to map the micro-topography of MI and the changes it underwent during the course of the experiment. The model used was the Gocator 3110 which allows high frequency analyses (i.e. a scan rate of $5 \mathrm{~Hz}$ ). MI were assessed in pairs, a blue light $(465 \mathrm{~nm})$ and a stereo scan were performed of each surface face to build a numerical relief.

Chlorophyll a extractions. In order to convert the biomass proxy $\mathrm{F}_{0}$ into $\mathrm{Chl}$ a biomass, $15 \mathrm{MI}$ were specially incubated in the same condition as those of this experiment. Then, chlorophyll $a(\mathrm{Chl} a)$ was extracted from MPB biofilms sampled on these MI after incubation for 7, 14 and 28 days. The MPB biofilm was sampled with a soft toothbrush on MI upper faces and then diluted in $250 \mathrm{ml}$ of filtered sea water (Stericup GV Millipore, Ø $0.22 \mu \mathrm{m}$ ). A sub-sample $(150 \mathrm{ml})$ of the diluted sample was filtered through a glass-fibre filter (Whatman, GF/F, $47 \mathrm{~mm}, 0.7 \mu \mathrm{m}$ ) and immediately frozen at $-20^{\circ} \mathrm{C}$ until analysis. A10$\mathrm{ml}$ aliquot of $90 \%$ acetone $(\mathrm{v} / \mathrm{v})$ was added for pigment extraction and the sample was then left at $4{ }^{\circ} \mathrm{C}$ in the dark for $12 \mathrm{~h}$. After two 5-min centrifugations at $1,700 \mathrm{~g}$, the $\mathrm{Chl} a$ concentration of the extracts was measured using a Trilogy fluorimeter (Turner Designs, Sunnyvale, USA) according to Strickland and Parsons (1968). These data allowed estimation of a factor between $\mathrm{F}_{0}$ and $\mathrm{Chl} a$ calculated for 15 samples. The conversion factor calculated was:

$$
\frac{F_{0}}{C h l a}=0.362
$$

with Chl $a$ expressed in $\mu \mathrm{g} \mathrm{cm} \mathrm{cm}^{-2}, R^{2}=0.365$ and $n=99$.

\section{Data treatment and analysis}

A MATLAB C) routine (available upon request) was developed to determine the values of each level of fluorescence $\left(F_{0}, F_{M}, F_{S}\right.$ (steady state fluorescence) and $F_{M^{\prime}}$ ) for each pixel. For each sample, auto-fluorescence was deducted and the images corresponding to all successive actinic light per RLC were nested in a 3-D matrix. A colour value was assigned to each 


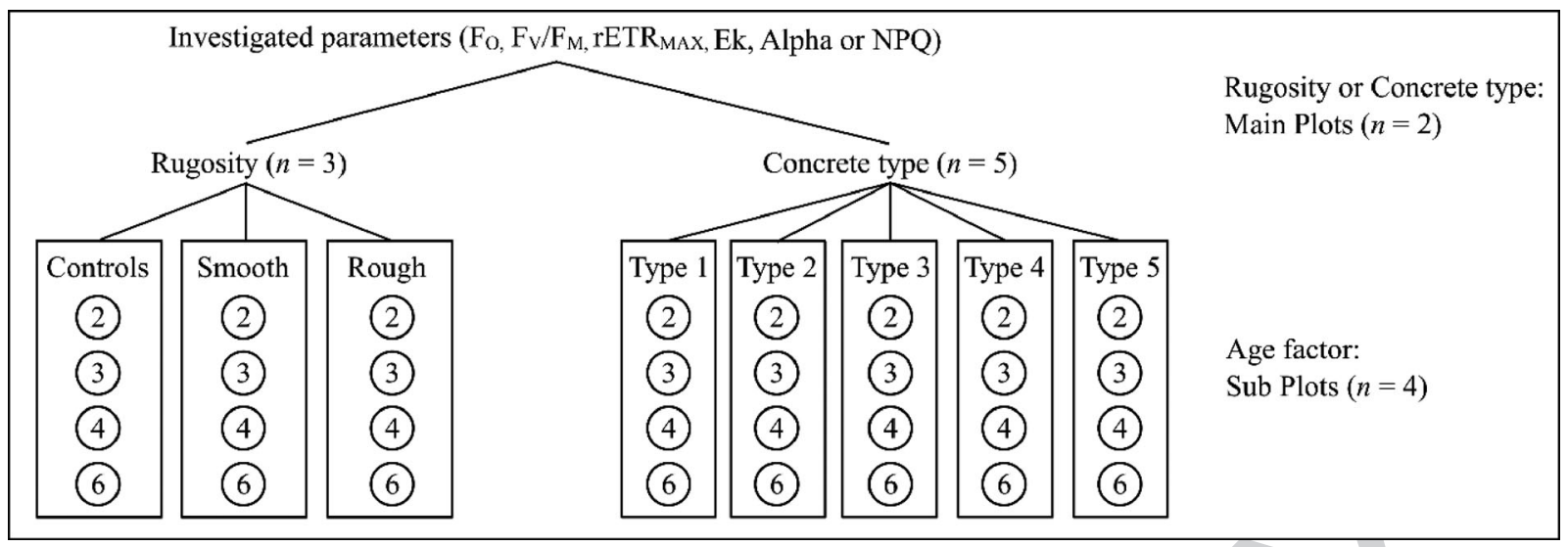

Figure 2. Diagram of the split-plot ANOVA design. For each of the four investigated parameters, the same design was applied with roughness and type of concrete in the main plots and age factor in the subplots.

gravy level and, using a conversion index (based on the fluorescence-colour scale provided by PAM software), each pixel was converted into a numerical value. The quantum efficiency of PSII charge separation $\left(\Delta \mathrm{F} / \mathrm{F}_{\mathrm{M}}\right.$; fluorescence ratio) was calculated for

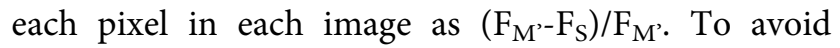
noise bias during imaging-PAM measurements, all $\mathrm{F}_{\mathrm{M}}$ values below 0.048 were previously considered invalid. Indeed, below this threshold, the values acquired were too weak to be reliable (Heinz Walz GmbH 2014). Subsequently, for each pixel and actinic light (E; $\mu \mathrm{mol}$ photons $\mathrm{m}^{-2} \mathrm{~s}^{-1}$ ), the relative electron transport rate was estimated $\left(r E T R=\Delta F / F_{M}, x E\right)$, rETR-I curves were performed and the acclimatisation light (Ek, $\mu$ mol photons $\mathrm{m}^{-2} \mathrm{~s}^{-1}$ ) was estimated. Microtopography data obtained with the $3 \mathrm{D}$ camera were also exploited with a MATLAB ${ }^{\mathcal{C}}$ routine in order to calculate the correlation between several indicators $\left(\mathrm{F}_{0}, \mathrm{~F}_{\mathrm{V}} / \mathrm{F}_{\mathrm{M}}, \mathrm{rETR}_{\mathrm{MAX}}, \mathrm{Ek}, \alpha\right.$ and $\left.\mathrm{NPQ}\right)$ and the rugosity level. An upstream treatment allowed correction of the potential inclination of the MI upper face with the following polynomial equation:

$$
Z_{\text {interp }}=\mathrm{a} \times \mathrm{X}+\mathrm{b} \times \mathrm{Y}+\mathrm{c} \times \mathrm{X} . \mathrm{Y}+\mathrm{d}
$$

with $\mathrm{X}$ and $\mathrm{Y}$ the inferior limits of the MI. The parameters a, b, c and d were obtained with a simplex minimisation method allowing the determination of the better equation (higher $\mathrm{R}^{2}$ ) passing through the surface plan $\left(Z_{0}\right)$. In order to determine the exact surface microtopography without possible inclination plan interferences, it was necessary to remove it. The difference between these values was calculated for each pixel as follows:

$$
Z_{\text {final }}=Z_{0}-Z_{\text {interp }}
$$

Data analysis was performed with R i386 3.5.1 (R Development Core Team 2008). Factors were organised in a partial hierarchical design with three fixed factors: age (2, 3, 4 or 6 days), roughness (rough, smooth or PVC), type of concrete (1 to 5). Data normality was tested (Shapiro-Wilk normality test) and, if necessary, data were transformed with the boxcox function of the MASS package on R. A split-plot ANOVA design was performed involving crossed factors see Potvin (1993) for a detailed description (Figure 2) and Supplementary material. Tukey tests were performed to distinguish any significant differences between several variables of a factor. Pearson correlation tests were also performed between the degree of roughness and each physiological indicator. Imaging-PAM and 3-D camera analyses were performed 2, 3, 4 and 6 days after the beginning of the experiment on every MI.

\section{Results}

\section{Environmental conditions and species identification}

Mesocosm temperature varied slightly from $18.6^{\circ} \mathrm{C}$ to $21.4^{\circ} \mathrm{C}$ from day 2 to 6 while the $\mathrm{pH}(+/-8.3)$ remained constant throughout the experiment. The light intensity at the surface of the MI was on average $113.83 \mu \mathrm{mol}$ photons $\mathrm{m}^{-2} \mathrm{~s}^{-1}$ for $8 \mathrm{~h}$ (from 8 am to $4 \mathrm{pm}$ ) every day of the survey.

SEM observations revealed a wide diversity of MPB species in different proportions (Figure 3). Cylindrotheca closterium was abundant. Many MPB biofilm fragments with high densities of cells embedded in a matrix of EPS were found with a wide range of genera including Amphora sp., C. closterium, Entomoneis sp., Hantzschia sp., Microtabella sp., Thalassiosira sp., and some choanoflagellates. 

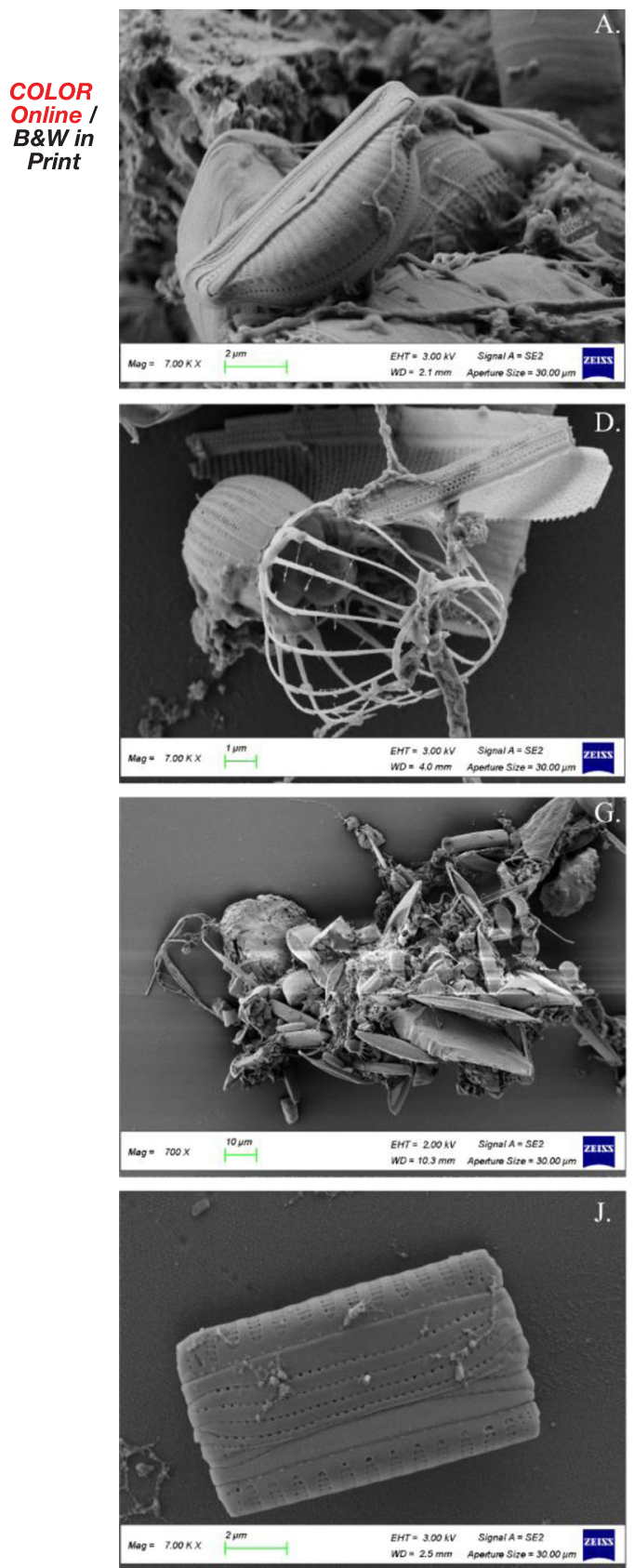
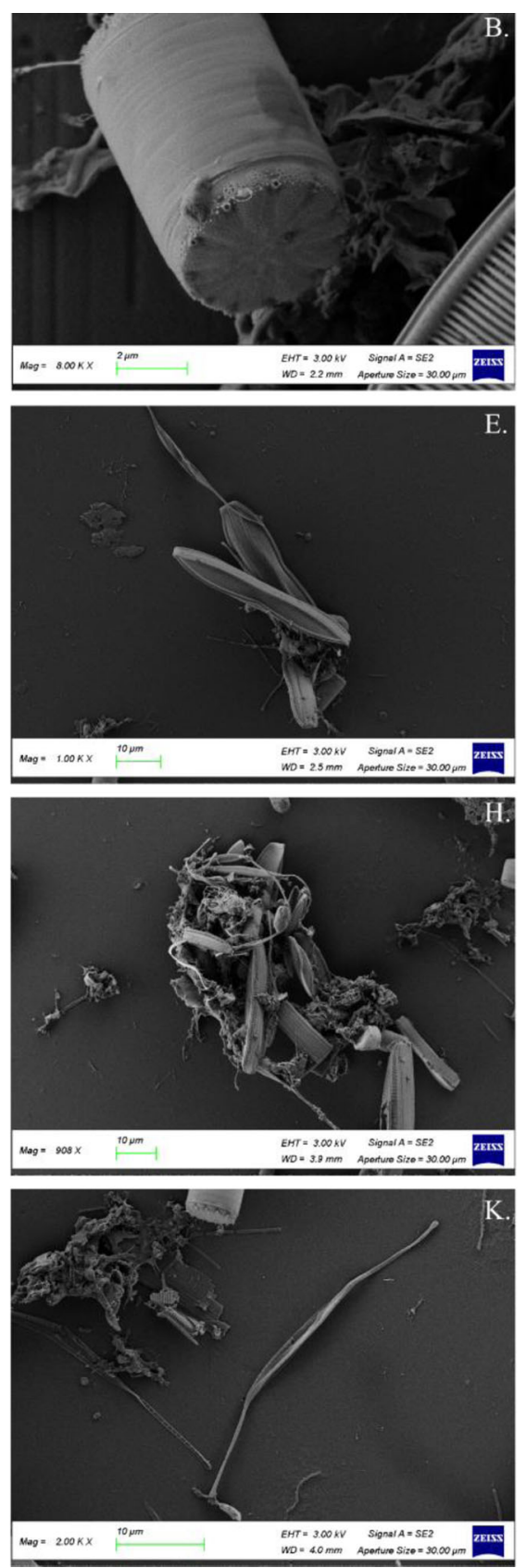
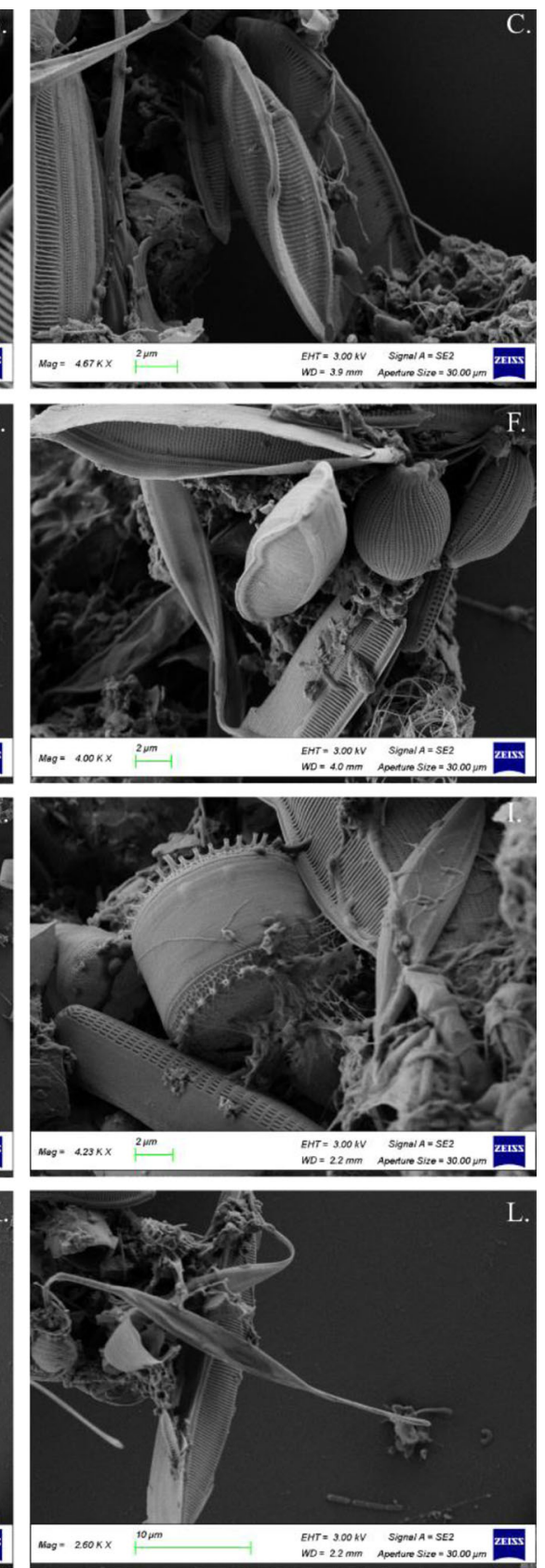

Figure 3. SEM observations of microphytobenthic biofilms sampled on one rough $\mathrm{Ml}$ at the end of the experiment. Amphora sp. (A); Thalassiosira sp. (B); Entomoneis sp. (C and E); choanoflagellate (D); Hantzschia sp. in the centre (F); high densities of cells embedded in a matrix of EPS (G and H); Thalassiosira sp. (I); Microtabella sp. (J); Cylindrotheca closterium (K); C. closterium in the centre (L).

\section{Biological parameters varied with the substratum}

\section{Chl a biomass}

The averaged value of $\mathrm{Chl} a\left(\mu \mathrm{g} \mathrm{cm}^{-2}\right)$ was calculated for each MI (PVC, rough and smooth) at each sampling point, from day 2 to day 6 after the start of the experiment (Figure 4A). On PVC structures, Chl $a$ showed a slight increase from $0.0235+/-0.0039 \mu \mathrm{g}$ $\mathrm{cm}^{-2}$ (standard deviation) to $0.0273+/-0.0083 \mu \mathrm{g}$

$\mathrm{cm}^{-2}$ between day 2 and $6\left(+0.0038 \mu \mathrm{g} \mathrm{cm}^{-2}\right)$. On smooth MI, it increased slightly from $0.0047+/-$ 0.0021 and $0.0113+/-0.0042 \mu \mathrm{g} \mathrm{cm}^{-2}$ between day 3 and $6\left(+0.0066 \mu \mathrm{g} \mathrm{cm}^{-2}\right)$. On the rough $\mathrm{MI}$, it increased from $0.0091+/-0.0028$ and $0.0148+/-$ $0.0027 \mu \mathrm{g} \mathrm{cm}^{-2}\left(+0.0057 \mu \mathrm{g} \mathrm{cm}^{-2}\right)$. According to the split-plot ANOVA (Supplementary material), there was a significant effect of roughness, type of concrete and age on the MPB biomass. An HSD Tukey test
690

691

692

693

694

695

696

697

698

699

700

701

702

703

704

705

706

707

708

709

710

711

712

713

714

715

716

717

718

719

720

721

722

723

724

725

726

727

728

729

730

731

732

733

734

735

736

737

738
739

739
740

740

741

742 

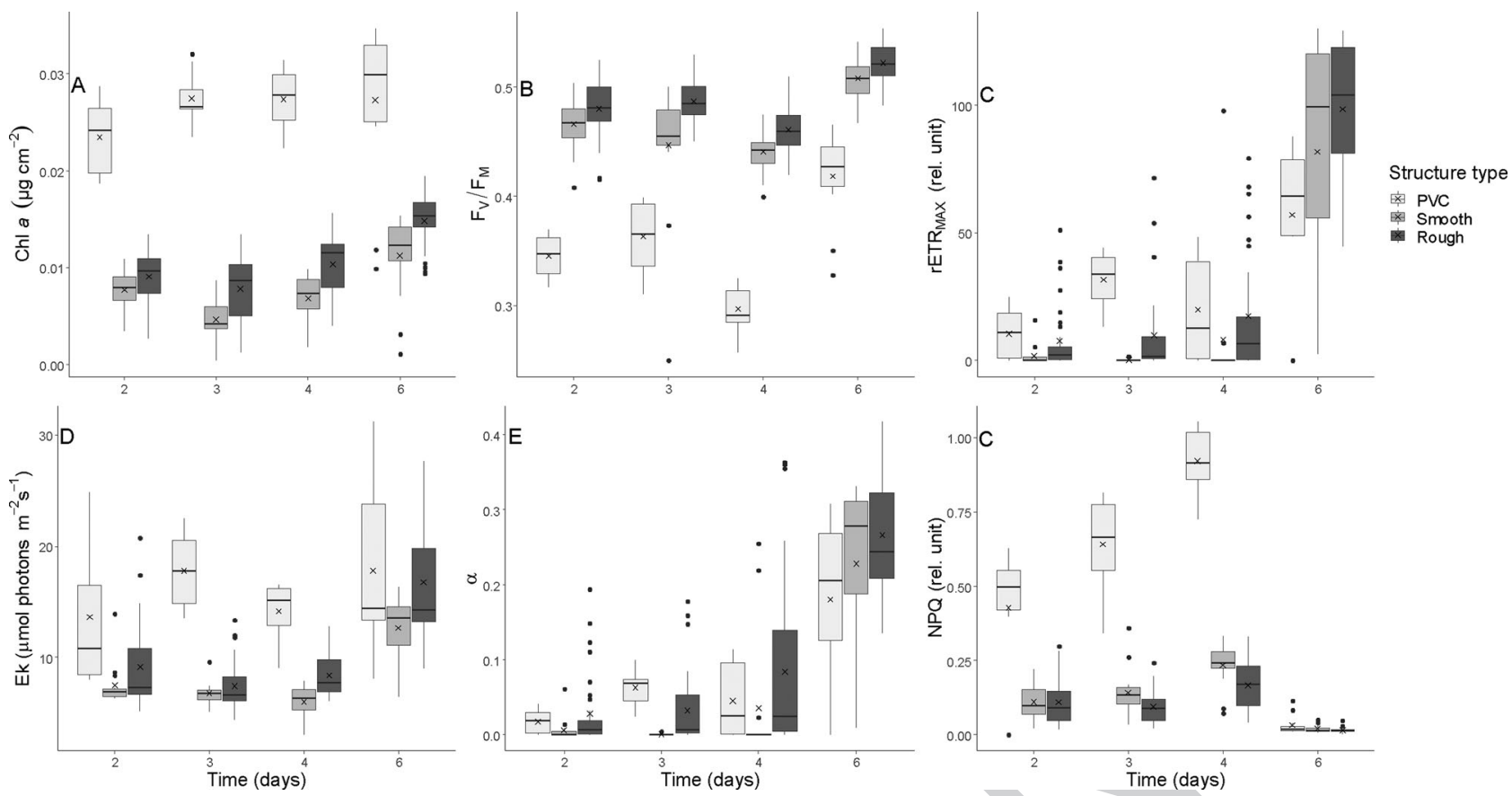

Figure 4. MPB biomass $\left(A, \mu \mathrm{g} \mathrm{Chl} a \mathrm{~cm}^{-2}\right)$ and photosynthetic indicators $F_{V} / F_{M}(B), r E T R_{M A X}(C$, relative unit), Ek (D, $\mu$ mol photons $\left.\mathrm{m}^{-2} \mathrm{~s}^{-1}\right), \alpha\left(E, \mu \mathrm{mol}\right.$ electrons ( $\mu \mathrm{mol}$ photons) $\left.{ }^{-1}\right)$ and NPQ ( $\mathrm{F}$, relative unit) assessment throughout the course of the 6-day experiment on the three different types of structure (PVC, rough and smooth).

(Supplementary material) revealed that each roughness differed significantly from the others. There was no significant difference between the types of concrete except for PVC controls. In both cases, the age factor had a significant effect on Chl $a$ after day 3 .

\section{Photosynthetic parameters}

Several photosynthetic parameters were analysed with Imaging-PAM by also providing an estimate of their spatial variations. $\mathrm{F}_{\mathrm{V}} / \mathrm{F}_{\mathrm{M}}$ (Figure $4 \mathrm{~B}$ ) of the $\mathrm{PVC}$ structures remained constant during the first three days (between $0.35+/-0.02$ and $0.36+/-0.03$ ), it decreased on the fourth day to $0.30+1-0.02$ and increased to $0.42+/-0.04$ on the last two days. $\mathrm{F}_{\mathrm{V}} /$ $\mathrm{F}_{\mathrm{M}}$ for rough and smooth surfaces faces showed the same dynamics, remaining constant for the first three days, decreasing slightly on day 4 and finally increasing until day 6. On the rough surfaces, photosynthetic yields $\mathrm{F}_{\mathrm{V}} / \mathrm{F}_{\mathrm{M}}$ reached $0.52+/-0.02$ at the end of the experiment. A value of $\mathrm{F}_{\mathrm{V}} / \mathrm{F}_{\mathrm{M}}$ of $0.51+/-0.02$ was measured on smooth surfaces at day 6. According to the split plot ANOVA (Supplementary material), there was a significant effect of roughness, type of concrete, and age on $\mathrm{F}_{\mathrm{V}} / \mathrm{F}_{\mathrm{M}}$, but not of the interaction between age and roughness, meaning that the temporal dynamics were comparable between the two surfaces and also with the PVC control. An HSD Tukey test (Supplementary material) revealed that each degree of roughness differed significantly from the others. There was a significant effect of age during the monitored biofilm growth, but no significant difference was found between the types of concrete except for the PVC controls, and the interaction term between type and age was not significant.rETR $\mathrm{MAX}_{\mathrm{MA}}$ (Figure 4C) increased slightly on the PVC controls from $10.35+/-9.81$ relative unit to $31.64+/-10.98$ relative unit between day 2 and 3, decreased to 19.89 $+/-20.83$ relative unit at day 4 and increased again to reach $57.02+/-30.49$ relative unit at the end of the experiment. On rough structures, $\mathrm{rETR}_{\mathrm{MAX}}$ increased progressively throughout the experiment from $7.69+/-13$ relative unit at the first sampling point to $98.51+/-25.95$ relative unit at day 6 . Finally, $\mathrm{rETR}_{\mathrm{MAX}}$ of smooth structures remained very low for four days (below $1.75+/-4.03$ relative unit) and reached $81.89+/-45.93$ relative unit on the last day. According to the split-plot ANOVA (Supplementary material), there was a significant effect of roughness, the type of concrete, and age on

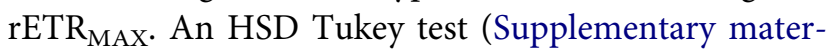
ial) revealed that smooth surfaces differed significantly from the others. There was no significant difference between the types of concrete except for the PVC controls. The age factor had a significant effect on rETR $_{\text {MAX }}$ at day 6 .

Ek (Figure 4D) values for PVC structures decreased slightly from $4.28+/-7.41 \mu \mathrm{mol}$ photons $\mathrm{m}^{-2} \mathrm{~s}^{-1}$ to $3.68+/-6.80 \mu \mathrm{mol}$ photons $\mathrm{m}^{-2} \mathrm{~s}^{-1}$
800

801

802

803

804

805

806

807

808

809

810

812

813

814

815

816

817

818

819

820

821

822

823

824

825

826

827

828

829

830

831

832

833

834

835

836

837

838

839

840

841

842

843

844

845

846

848 
between day 2 and day 4 before increasing to reach $9.16+/-11.71 \mu \mathrm{mol}$ photons $\mathrm{m}^{-2} \mathrm{~s}^{-1}$ at day 6 . On rough structures, Ek remained stable between 2.77 $+/-3.71 \mu \mathrm{mol}$ photons $\mathrm{m}^{-2} \mathrm{~s}^{-1}$ and $3.90+/-$ $5.11 \mu \mathrm{mol}$ photons $\mathrm{m}^{-2} \mathrm{~s}^{-1}$ until day 4 before increasing to reach $6.56+/-8.67 \mu \mathrm{mol}$ photons $\mathrm{m}^{-2} \mathrm{~s}^{-1}$ at day 6. Finally, Ek decreased slightly on smooth structures with between $3.28+/-3.65 \mu \mathrm{mol}$ photons $\mathrm{m}^{-2}$ $\mathrm{s}^{-1}$ and $1.65+/-2.71 \mu \mathrm{mol}$ photons $\mathrm{m}^{-2} \mathrm{~s}^{-1}$ between day 2 and day 4 before reaching $5.08+/-$ $6.27 \mu \mathrm{mol}$ photons $\mathrm{m}^{-2} \mathrm{~s}^{-1}$ at day 6 . There was no significant effect of roughness or of the type of concrete on Ek, only a significant effect of age was found on Ek (split-plot ANOVA, $p<0.001^{* * *}$ ). The HSD Tukey test indicated that the age factor had a significant effect, with a difference that was particularly apparent on the last day. Interaction terms with time were not significant, whatever the factor (roughness or type of material).

$\alpha$ (Figure 4E) showed a slight increase on PVC structures from $0.0175+/-0.0158 \mu \mathrm{mol}$ electrons

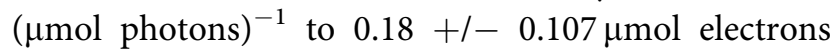
$(\mu \mathrm{mol} \text { photons })^{-1}$ between days 2 and 4 . $\alpha$ was almost null during the first three days on smooth MI and reached $0.228+/-0.115 \mu \mathrm{mol}$ electrons $(\mu \mathrm{mol}$ photons $)^{-1}$ on the last day. On rough MI, it increased continuously from $0.028+/-0.049 \mu \mathrm{mol}$ electrons $(\mu \mathrm{mol} \text { photons })^{-1}$ to $0.266+/-0.0745 \mu \mathrm{mol}$ electrons

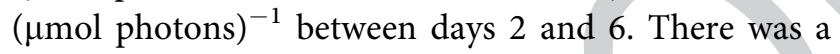
significant effect of roughness, the type of concrete and age on $\alpha$ (split-plot ANOVA, $p<0.001^{* * *}$ ). HSD Tukey test (Supplementary material) revealed that $\alpha$ differed significantly on rough and smooth MI. Age also affected $\alpha$, there were significant differences between each day except between days 3 and 4 . The type of concrete type also had an impact on $\alpha$ and there was a significant difference between type 4 and 5 .

The NPQ was determined under the experimental light conditions $\left(113 \mu \mathrm{mol}\right.$ photons $\left.\mathrm{m}^{-2} \mathrm{~s}^{-1}\right)$ (Figure $4 \mathrm{~F}$ ) and showed a strong increase on PVC from 0.427 $+/-0.210$ to $0.921+/-0.103$ between days 2 and 4 before falling to $0.033+/-0.033$ on the last day. On smooth MI, it increased from $0.111+/-0.057$ to $0.234+$ S- 0.075 between days 2 and 4 before reaching $0.021+/-0.014$ at day 6 . On rough MI, NPQ increased from $0.110+/-0.077$ to $0.167+/-0.079$ during the first four days then fell to $0.0161+/-$ 0.009 on day 6. There was a significant effect of roughness and age on NPQ (split-plot ANOVA, $p<0.001^{* * *}$ ). An HSD Tukey test (Supplementary material) showed that NPQ on PVC always differed significantly from smooth and rough NPQ. Age also affected NPQ: there were significant differences between each day except between days 2 and 3 . Finally, the type of concrete did not affect the NPQ except for type $\mathrm{n}^{\circ} 3$ and $\mathrm{n}^{\circ} 5$ (PVC).

\section{Biofilm colonisation depending on the microtopography}

\section{Microphytobenthic biomass distribution}

The spatial distribution of $\mathrm{F}_{0}$ was very heterogenous on the rough surfaces. On the second day, there was no MPB biomass on the high positive relief of the rough surfaces. During the entire experiment, there were more MPB cells on the negative reliefs than on the positive ones (millimetric scale). On the last day of the experiment, MPB biomass was present on the positive reliefs, but the quantities were smaller than on the negative ones (Figure 5). The MPB biomass was distributed differently between the smooth and rough structures at the same sampling point. The spatial distribution of $\mathrm{F}_{0}$ was less heterogeneous on the smooth MI than on the rough ones throughout the survey (Figure 6).

\section{Distribution of microphytobenthic photosyn-} thetic indicators

The $\mathrm{F}_{\mathrm{V}} / \mathrm{F}_{\mathrm{M}}$ distribution was also notably heterogeneous on the rough MI (Figure 5) compared with the smooth one (Figure 6). Its distribution seemed to be affected by the relief. $\mathrm{rETR}_{\mathrm{MAX}}$ and awere also affected by the surface roughness on the rough MI, while these parameters were not correctly graphically represented on smooth MI. The NPQ also seemed to be affected by the MI topography, on rough MI, NPQ appeared was on high positives reliefs. On smooth ones, NPQ seemed to be more homogenously distributed.

\section{Correlation between microtopography and MPB} biomass or photosynthetic indicators

Correlation coefficients (R) were calculated between the level of microtopography (negative or positive) and the $\mathrm{F}_{0}, \mathrm{~F}_{\mathrm{V}} / \mathrm{F}_{\mathrm{M}}, \mathrm{rETR}_{\mathrm{MAX}}, \mathrm{Ek}, \alpha$ and NPQ. R $>0.1$ or $<-0.1$ were considered as significantly positive or negative (critical values in a Student's $t$ test with this sample pixel number). A positive $\mathrm{R}$ indicated that the indicator was mostly measured on positive reliefs and, conversely, a negative $\mathrm{R}$ indicated that the indicator was mostly measured on negative ones.

The correlation between roughness and surface Chl a biomass was calculated (Figure 7A). Correlation
902

903

904

905

906

907

908
909

910

911

912

913

914

915
916

916
917

918

919

920

921

922

923

924

925

926

927
928

929

930

931

932

933

934

935

936
937

938

939

940

941

942

943

944

945
946

947

948

950

951

952

953

954 
955

956

957

958

959

960

961

962

963

964

965

966

967

968

969

970

971

972

973

974

975

976

977

978

979

980

981

982

983

984

985

986

987

988

989

990

991

992

993

994

995

996

997

998

999

1000

1001

1002

1003

1004

1005

1006

1007

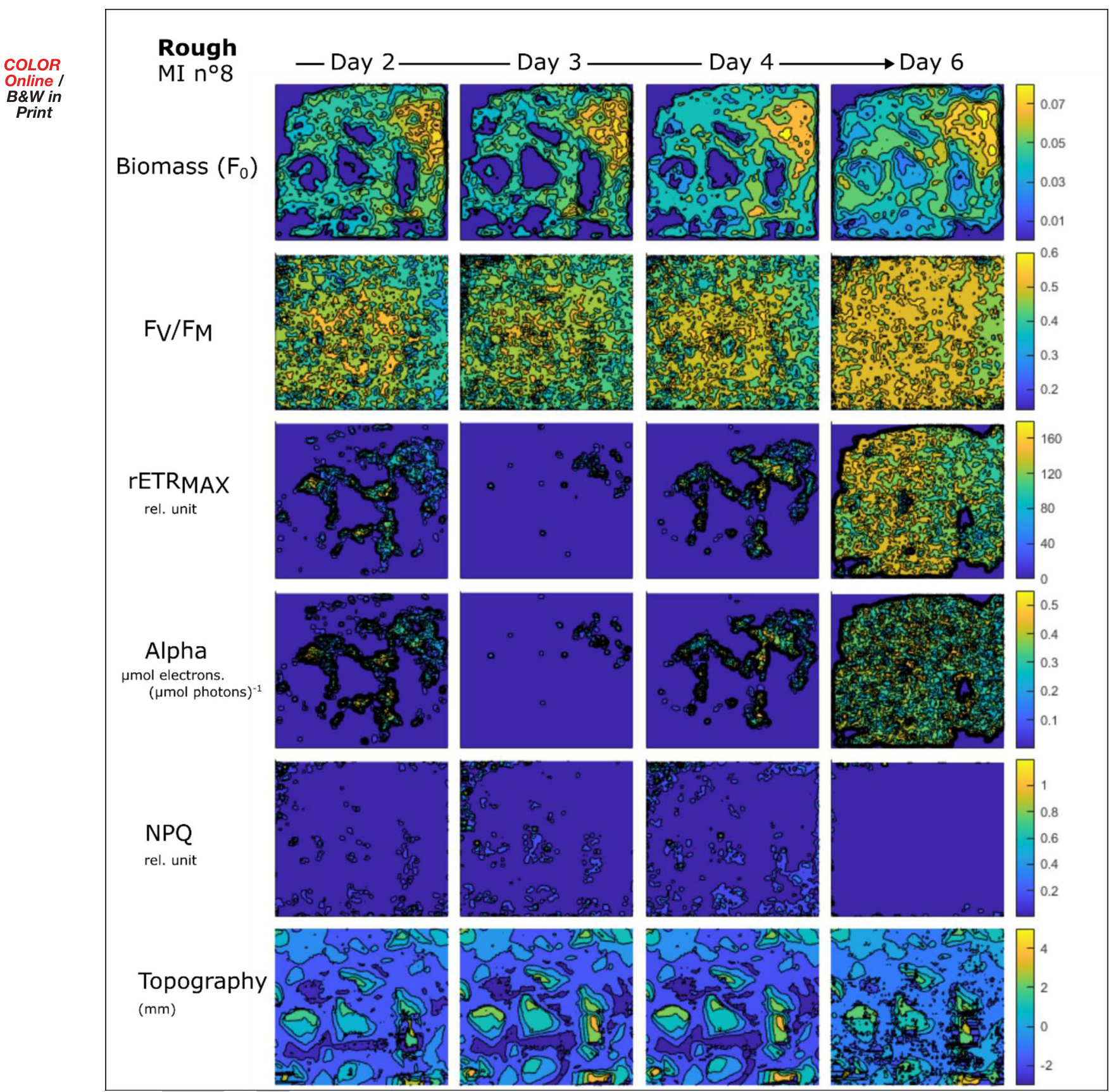

Figure 5. Spatial distribution of biofilm biomass $\left(F_{0}\right)$ and selected photosynthetic indicators $\left(F_{V} / F_{M}, r E T R_{M A X}\right.$ (relative unit), Alpha ( $\mu \mathrm{mol}$ electrons ( $\mu \mathrm{mol}$ photons)- 1 ) and NPQ (relative unit)) and microtopography $(\mathrm{mm})$ on one rough $\left.\mathrm{BMI}^{\circ} \mathrm{n}^{\circ} 8\right)$ during the monitoring period.

coefficients were always higher than 0 on PVC or smooth structures throughout the survey. In these cases, the correlation was quite similar throughout the survey. On rough structures, correlation coefficients were significantly lower than 0 and varied between $-0.17+/-0.2$ at day 2 and $-0.083+/-0.17$ on the last day. On rough structures, the correlation coefficient also differed significantly from that on the two other structures $\left(p<0.01^{* *}\right)$.
The correlation between roughness and $\mathrm{F}_{\mathrm{V}} / \mathrm{F}_{\mathrm{M}}$ was calculated (Figure 7B). The R coefficient on PVC or smooth structures was always positive throughout the experiment and its dynamics was almost the same in the two cases. It increased slightly from $0.068+/-$ 0.1 to $0.082+/-0.11$ between day 2 and day 6 on smooth structures. On PVC structures, it increased slightly from $0.067+/-0.087$ to $0.14+/-0.05$ between day 2 and the last day of experiment. The $\mathrm{R}$ 
1061

1062

1063

1064

1065

1066

1067

1068

1069

1070

1071

1072

1073

1074

1075

1076

1077

1078

1079

1080

1081

1082

1083

1084

1085

1086

1087

1088

1089

1090

1091

1092

1093

1094

1095

1096

1097

1098

1099

1100

1101

1102

1103

1104

1105

1106

1107

1108

1109

1110

1111

1112

1113

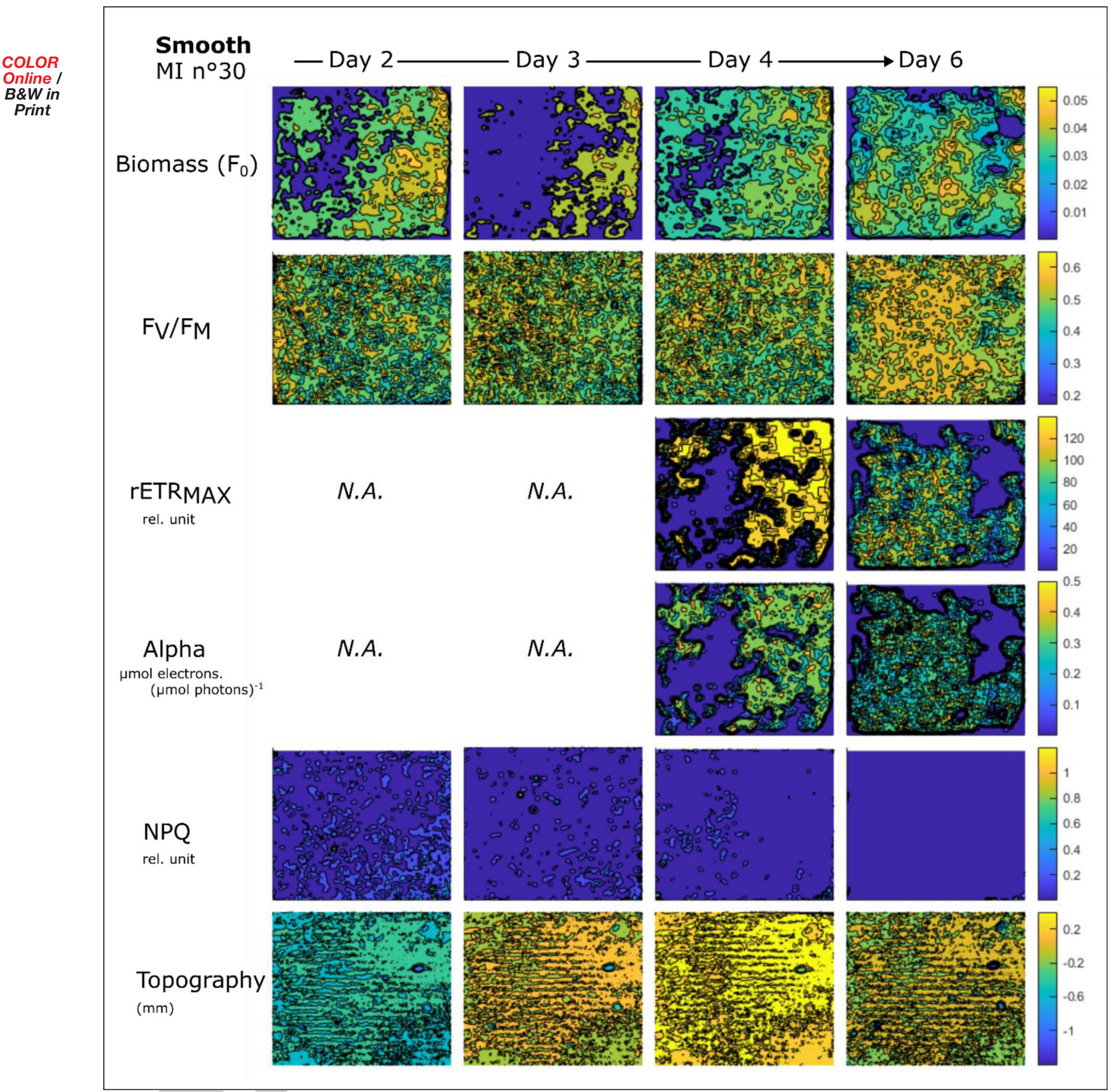

Figure 6. Spatial distribution of biofilm biomass $\left(F_{0}\right)$ and selected photosynthetic indicators $\left(F_{V} / F_{M}, r E T R_{M A X}\right.$ (relative unit), Alpha ( $\mu \mathrm{mol}$ electrons ( $\mu \mathrm{mol}$ photons)-1) and NPQ (relative unit)) and microtopography $(\mathrm{mm})$ on one smooth $\mathrm{BMI}\left(\mathrm{n}^{\circ} 30\right)$ during the monitoring period.

coefficient on rough structures was notably lower than 0 and varied between $-0.13+/-0.15$ at day 2 and $-0.05+/-0.16$ on the last day. The correlation coefficient on rough structures also differed significantly different from that of the two other structures $\left(p<0.01^{* *}\right)$.

The correlation between roughness and $\mathrm{rETR}_{\mathrm{MAX}}$ was calculated (Figure 7C). There were no significant differences between smooth and control structures. The correlation coefficient for the controls ranged between $0.057+/-0.093$ and $0.075+/-0.083$ from day 2 until the last day of the experiment. On smooth structures, it varied between $0.046+/-0.095$ and 0.048 $+/-0.11$ over the same period. There was a significant difference between the rough surface and the two other surfaces $\left(p<0.001^{* * *}\right)$. The correlation coefficient varied between $-0.035+/-0.27$ and $-0.005+/-0.13$ between day 2 and the last day of the experiment.

The correlation between roughness and Ek was calculated (Figure 7D). Its dynamics were similar in the 
1167

1168

1169

1170

1171

1172

1173

1174

1175

1176

1177

1178

1179

1180

1181

1182

1183

1184

1185

1186

1187

1188

1189

1190

1191

1192

1193

1194

1195

1196

1197

1198

1199

1200

1201

1202

1203

1204

1205

1206

1207

1208

1209

1210

1211

1212

1213

1214

1215

1216

1217

1218

1219
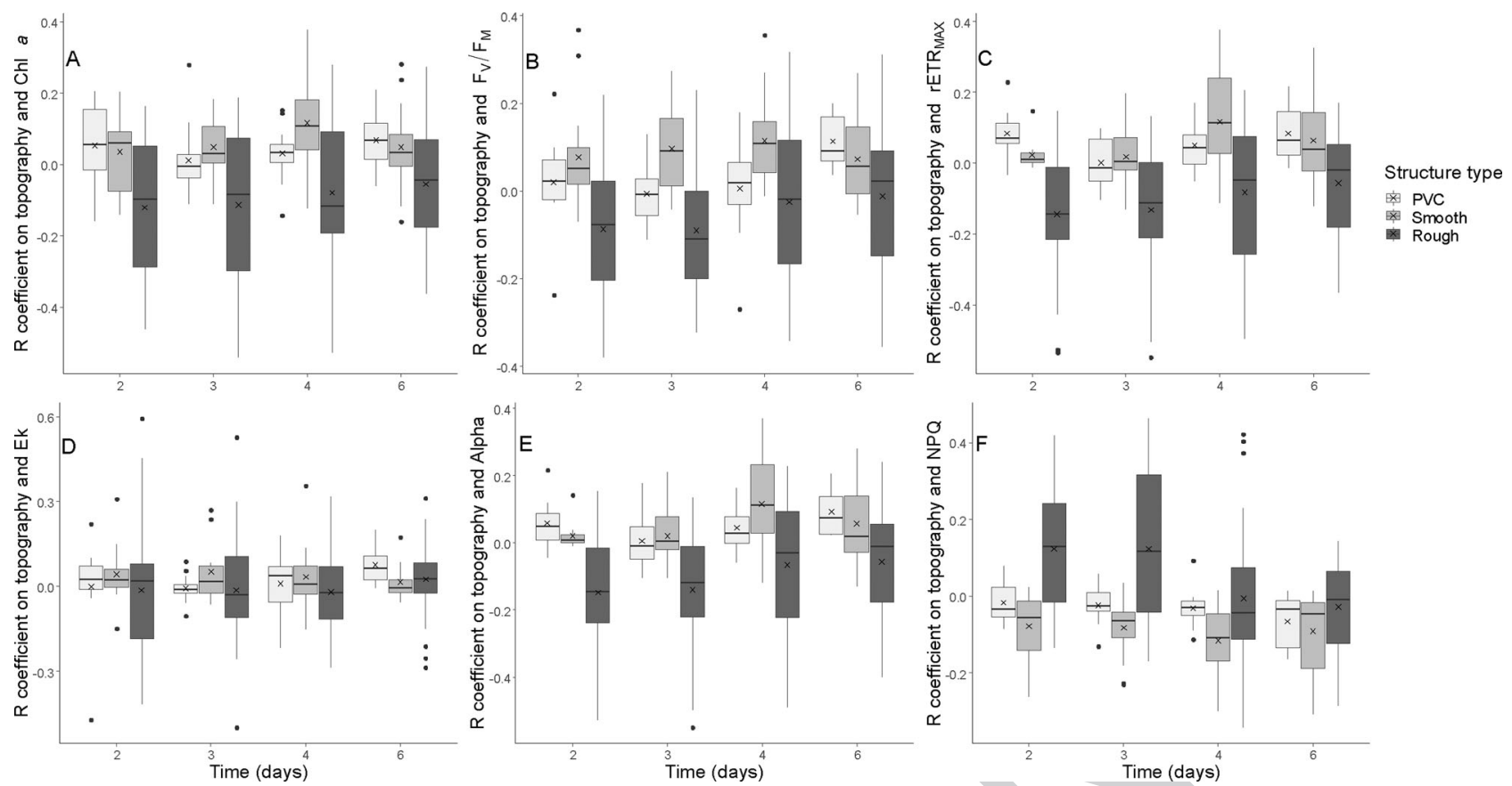

Figure 7. Spatial distribution of selected photosynthetic indicators, $C h l$ a $(A), F_{V} / F_{M}(B), r E T R_{M A X}(C), E k(D), \alpha(E)$ and NPQ (F) and microtopography $(\mathrm{mm})$ on one rough $\mathrm{BMI}\left(\mathrm{n}^{\circ} 8\right)$ during the monitoring period.

three types of structure and no significant difference was found between them.

The correlation between $\alpha$ and surface roughness was calculated (Figure 7E). On rough MI, it was significantly lower than on the others $\left(p<0.001^{* * *}\right)$. There also was a significant difference between the first two days and the two last days of the experiment. On rough MI, the coefficient varied from $-0.15+/-0.17$ and -0.056 $+/-0.16$ between day 2 and day 6 . On smooth MI, it varied between $0.021+/-0.041$ and $0.057+/-0.13$ during the experiment. On PVC, it varied from 0.059 $+/-0.079$ and $0.093+/-0.073$ between day 2 and 6 .

Finally, the correlation between the NPQ and the roughness was calculated (Figure $7 \mathrm{~F}$ ). There was a significant impact of roughness $\left(p<0.001^{* * *}\right)$ and age $\left(p<0.001^{* * *}\right)$ on NPQ. NPQ was always significantly higher on rough $\mathrm{MI}$ than on the others. It was higher than 0 during the first three days on rough MI and varied between $0.12+/-0.17$ and $-0.028+/-0.12$ from day 2 to day 6 . On smooth MI, NPQ varied from $-0.078+/-0.095$ and $-0.091+/-0.1$ between day 1 and day 6. On PVC, it varied between $-0.017+/-$ 0.059 and $-0.066+/-0.07$ between day 2 and day 6 .

This analysis revealed that the correlation between the level of microtopography and $\mathrm{F}_{\mathrm{O}}, \mathrm{F}_{\mathrm{V}} / \mathrm{F}_{\mathrm{M}}$ and $\mathrm{rETR}_{\mathrm{MAX}}$ was significantly lower on the rough structures than on the smooth ones and on the controls. Moreover, this correlation coefficient was also negative. On the controls and the smooth structures, the correlation coefficient was close to zero and on all structures the $\mathrm{R}$ coefficient showed a slight increase on the last day of experiment.

\section{Discussion}

\section{Influence of the substratum on biofilm}

\section{development and its physiological quality}

In dark adapted microalgae, most of the $\mathrm{F}_{0}$ originates from the Chl $a$, a correlation between $\mathrm{F}_{0}$ and Chl $a$ is often used in oceanography and in biofilm studies (Barranguet and Kromkamp 2000; Stock 2019). The present results show a large and significant difference in Chl $a$ concentrations between PVC and concrete structures throughout the experiment. The MPB biomass on these structures remained constant throughout the experiment. This observation confirmed that this material can be easily and efficiently colonised by MPB. These first colonisation steps are primordial before the establishment of subsequent ecological successions (Fonsêca-Genevois et al. 2006; Sokołowski et al. 2017). Two days after the start of the experiment, the volume of Chl $a$ biomass was more than two times lower on concrete (rough and smooth) structures than on the PVC structures. Behind the fact that concrete led to slower growth of the MPB biofilm compared with PVC, Chl $a$ biomass was also always higher on rough surfaces than on the smooth ones and increased significantly after the third day. 
Table 2. Summary of the positive or negative effects of both variables (rugosity and concrete formulation) on the biofilm biomass $(\mathrm{Chl} a)$ and its associated photosynthetic parameters.

\begin{tabular}{|c|c|c|c|c|c|c|}
\hline & \multicolumn{3}{|c|}{ Rugosity } & \multicolumn{3}{|c|}{ Concrete formulation } \\
\hline & Control PVC & Smooth & Rough & Cement type I & Cement type II & Shell addition \\
\hline $\mathrm{Chl} a$ & Reference & & & Reference & $=$ & $=$ \\
\hline $\mathrm{F}_{\mathrm{V}} / \mathrm{F}_{\mathrm{M}}$ & Reference & + & ++ & Reference & $=$ & $=$ \\
\hline $\mathrm{rETR}_{\operatorname{MAX}}$ & Reference & + & + & Reference & $=$ & $=$ \\
\hline Ek & Reference & $=$ & $=$ & Reference & $=$ & $=$ \\
\hline$\alpha$ & Reference & + & ++ & Reference & $=$ & $=$ \\
\hline NPQ & Reference & & & Reference & $=$ & $=$ \\
\hline
\end{tabular}

Footnote to Table 2: The reference used for the rugosity variable were PVC plates and the reference used for the concrete formulation variable were cement type I.

However, these results seemed to confirm the influence of roughness on biofilm colonisation with slower growth on a more complex topography (AlmaguerFlores et al. 2012; Souche et al. 2016). The rapid uniform increase in MPB biomass on PVC structures compared with that on rough MI was an indicator of the poor ability of PVC material (i.e. smooth) to support gradual and sustainable biofilm establishment.

The maximum quantum efficiency of PSII $\left(\mathrm{F}_{\mathrm{V}} / \mathrm{F}_{\mathrm{M}}\right)$ was associated with the physiological state of the MPB (Kromkamp et al. 1998; Morris and Kromkamp 2003; Jesus et al. 2005). $\mathrm{F}_{\mathrm{V}} / \mathrm{F}_{\mathrm{M}}>0.5$, considered to be a good physiological status, has frequently been measured in marine benthic and phytoplankton microalgae (Kromkamp et al. 1998; Morris and Kromkamp 2003; Napoléon et al. 2013). The $F_{V} / F_{M}$ measured on PVC structures was significantly lower than on the concrete structures. The very rapid growth of biofilm on PVC did not result in a resilient biofilm: microalgae rapidly showed evidence of a poor physiological status. The MPB colonising the concrete structures were in a better physiological state, confirmed by $F_{V} / F_{M}$ values close to 0.5 . This difference could be explained by the higher density of MPB measured on PVC structures leading to an increase in competition for light or nutrients and may have caused stress. Decreases in $\mathrm{F}_{\mathrm{V}} / \mathrm{F}_{\mathrm{M}}$ have also been associated with high NPQ values. At the same time, the slight difference in $\mathrm{F}_{0}$ and $\mathrm{F}_{\mathrm{V}} / \mathrm{F}_{\mathrm{M}}$ values between rough and smooth concrete structures throughout the experiment could also be explained by the microhabitats created by the roughness. Indeed, in complex microtopography, small crevasses were observed where diatoms found refuge from excess light or erosion. There, they can better cope with stressful environmental conditions, as revealed by the gentle and continuous increase in their photosynthetic performance. It is also known that excess light induced stresses which impacted the growth and photosynthetic performances of diatoms like C. closterium (Rijstenbil 2003; Roncarati et al. 2008) and may explain the better physiological parameters recorded for MPB biofilms on rough MI and the higher NPQ induction measured on PVC and smooth MI.

One expected consequence of a lower $\mathrm{F}_{\mathrm{V}} / \mathrm{F}_{\mathrm{M}}$ would be a parallel decrease in ETRR $_{\text {MAX }}$ and the photosynthetic efficiency (i.e. $\alpha$ ) because the energy captured by the PSII is diverted from photochemistry to nonphotochemical quenching (Ralph et al. 2002). However, the results suggest a better electron transport rate during the first three days of the experiment on the PVC structures. rETR $_{\text {MAX }}$ measurements also confirmed the better photosynthetic capacity of MPB on rough structures than on smooth ones, and this was also the case for photosynthetic efficiency. The falling NPQ values on the last day of experiment were concomitant with increasing rETR $_{\text {MAX }}$ values and could be explained by the settlement of a well photoacclimatised MPB biofilm. Additional measurements of $\mathrm{a}^{*}$ (Chl $a$ specific absorption coefficient) and $\sigma_{\text {PSII }}$ (functional absorption cross-section of PSII) would be useful to interpret the $\mathrm{rETR}_{\mathrm{MAX}}$ in more detail.

A dense MPB biomass with low photosynthetic parameters was recorded on PVC structures in contrast with concrete structures. Rough structures seemed to be more suitable for colonisation by a photosynthetically efficient biofilm. After day 6 of the experiment, some of the structures were kept in the tank with a photoperiod and the biofilm on the PVC detached itself into the water (visual observation on day 10). Even if these results were not acquired until the senescent phase on PVC, the data clearly confirm the weak efficiency of the PVC structures to be colonised by a competitive MPB compared with concrete ones. Table 2 summarise the qualitative effect of all variables on the biofilm. MPB biofilm colonising rough MI was dominated by benthic diatoms (Amphora sp., C. closterium, Entomoneis sp., Hantzschia sp. and Microtabella sp.) corresponding to native species and attesting to the potential of these structures to promote MPB biofilm development. The large number of cells embedded in the matrix of EPS 
observed by SEM confirmed the high physiological quality of these MPB biofilms. One of the most important criteria was the capacity of a structure to be colonised by a perennial biofilm leading to high photosynthetic performances and strong physical stability.

\section{Influence of microtopography on biofilm colonisation and several physiological indicators}

In order to explain the influence of roughness on these photosynthetic parameters in more detail, the microtopography of each structure was assessed over the course of the experiment and compared with MPB photosynthetic parameters. The combination of these techniques made it possible to accurately assess, pixel by pixel and on every sample, the distribution of each physiological indicator in accordance with the micro-topographic level.

Analyses of microphytobenthic communities can provide important insights for the evaluation of environmental status. Hard substratum marine biofilms have already been studied and these biofilms have been shown to be very diversified and abundant (Bulleri 2005; Bellou et al. 2012). Biofilms are influenced by several biotic and abiotic factors such as temperature (Di Pippo et al. 2012; Jackson et al. 2013), seasonality (Jackson et al. 2013; Orvain et al. 2014), grazing (Anderson 1995), currents (Battin et al. 2003), depth (Bellou et al. 2012) and light (Di Pippo et al. 2012). The structure and composition of the substrata may also affect the development of MPB but only a few studies have investigated these aspects to date. Autonomous Reef Monitoring Structures (ARMS) have been shown to be relatively easily colonised by MPB. Even if these structures had a smooth surface, they provide protection for biofilms and consequently facilitated colonisation (Pennesi and Danovaro 2017).

Many authors have examined the importance of roughness in the formation of biofilm, especially in medical sciences (Schwarz et al. 2007; Oh et al. 2009; Almaguer-Flores et al. 2012). Conversely, there have been few investigations on the impact of roughness on the formation of marine biofilms. In this study, the negative correlation between $\mathrm{Chl} a$ biomass, $\mathrm{F}_{\mathrm{V}} / \mathrm{F}_{\mathrm{M}}, \alpha$ and rETR $_{\mathrm{MAX}}$ and the degree of roughness on rough structures indicated that the MPB preferred microhabitats. This statement was supported by the fact that the correlation rates for these parameters also differed significantly between rough structures and smooth structures or controls. On the smooth surfaces of the concrete slabs, colonisation by the biofilm was observed edging towards the inside of the structure leading to a uniform biofilm at the scale of the surface. On the rough surfaces, colonisation by aggregation was highlighted. These foci of microphytobenthic colonisation appeared at the level of negative micro-relief anomalies. During the growth of the biofilms, the higher areas were gradually colonized towards the end of growth. No significant difference was found in the correlation coefficients between Ek and the level of roughness. Moreover, the assessment of NPQ indicated that photo-inhibition was higher on the high positive relief of rough MI and also on smooth faces of MI or PVC controls. These results show that roughness does affect the MPB biomass, its physiological state $\left(\mathrm{F}_{\mathrm{V}} / \mathrm{F}_{\mathrm{M}}\right)$, the $\mathrm{rETR}_{\mathrm{MAX}}$ and photosynthetic efficiency. Photo-inhibition processes could have been boosted by the high Chl a concentration and the absence of relief on smooth and PVC structures. It has been shown that diatom and cyanobacterial abundance are favourably affected by surface roughness on intertidal rock surfaces (Hutchinson et al. 2006). Souche et al. (2016) used a biomaterial similar to the concrete used in this study. They showed that increased roughness or the addition of bio-component like shells had a positive impact on algal colonisation. The influence of substratum topography or instability on MPB biomass is well known especially in intertidal mudflat systems where the diatom cover and biomass decrease in areas exposed to physical disturbances (Weerman et al. 2010). Taking the literature into account and considering the present results, it is clear that the most competitive MPB was observed on rough concrete structures, compared with the smooth structures, and was influenced by the millimetric amplitude of surface roughness and by the local microhabitats created by this higher micro-topography range. At a larger scale, e.g. ecosystem restoration projects or other applications, these results need to be taken into consideration. A more competitive biofilm will be more stable in the long run and will provide a better input for primary consumers, which is essential for the establishment of ecological successions (Anderson 1995; Jenkins et al. 2001; Hutchinson et al. 2006).

\section{Conclusions}

This study showed that concrete is a more suitable material for colonisation by a biofilm than PVC. The microhabitats represent micro-niches which were more colonised than the rest of the structure due to easier photoacclimation of the MPB in this microenvironment. In natural environments, the colonisation of MI by a competitive and physiologically active biofilm may promote the establishment of an 
ecological succession. These results are innovative for marine biofilms on hard substrata and confirm the importance of the addition of microhabitats for the creation of marine artificial structures designed for environmental restoration projects.

\section{Acknowledgements}

The results presented in this article were obtained in the collaborative project Interreg Va MARINEFF, selected under the European Cross-border Programme INTERREG FMA, and co-funded by the ERDF. The authors wish to thank the cofinanciers and all project partners for their support. The authors thank the Normandy Region for funding the IMAGING-PAM (CPER Manche 2021). The authors thank $\mathrm{Dr}$ Richard Retoux and $\mathrm{Mr}$ Xavier Larose of Laboratoire CRISMAT (Normandie University, ENSICAEN, UNICAEN, CNRS, CRISMAT, 14000 Caen, France) for technical SEM support for microscopy observations. The authors thank $\mathrm{Dr}$ Antoine Grémare and Alicia Romero Ramirez of the University of Bordeaux for the loan of the 3-D camera.

\section{Disclosure statement}

No potential conflict of interest was reported by the authors.

\section{ORCID}

Mohamed Boutouil (D) http://orcid.org/0000-0002-2752-8265

\section{References}

Almaguer-Flores A, Olivares-Navarrete R, Wieland $\mathrm{M}$, Ximénez-Fyvie LA, Schwartz Z, Boyan BD. 2012. Influence of topography and hydrophilicity on initial oral biofilm formation on microstructured titanium surfaces in vitro. Clin Oral Impl Res. 23:301-307. doi:10.1111/j. 1600-0501.2011.02184.x

Anderson MJ. 1995. Variations in biofilms colonizing artificial surfaces: seasonal effects and effects of grazers. J Mar Biol Ass. 75:705-714. doi:10.1017/S0025315400039114

Anderson MJ, Underwood AJ. 1994. Effects of substratum on the recruitment and development of an intertidal estuarine fouling assemblage. J Exp Mar Biol Ecol. 184: 217-236. doi:10.1016/0022-0981(94)90006-X

Bakker DP, Klijnstra JW, Busscher HJ, van der Mei HC. 2003. The effect of dissolved organic carbon on bacterial adhesion to conditioning films adsorbed on glass from natural seawater collected during different seasons. Biofouling. 19: 391-397. doi:10.1080/08927010310001634898

Barranguet C, Kromkamp J. 2000. Estimating primary production rates from photosynthetic electron transport in estuarine microphytobenthos. Mar Ecol Prog Ser. 204: 39-52. doi:10.3354/meps204039

Battin TJ, Kaplan LA, Newbold JD, Cheng X, Hansen C. 2003. Effects of current velocity on the nascent architecture of stream microbial biofilms. Appl Environ Microbiol. 69: 5443-5452. doi:10.1128/AEM.69.9.5443-5452.2003
Bellou N, Papathanassiou E, Dobretsov S, Lykousis V, Colijn F. 2012. The effect of substratum type, orientation and depth on the development of bacterial deep-sea biofilm communities grown on artificial substrata deployed in the Eastern Mediterranean. Biofouling. 28:199-213. doi:10.1080/08927014.2012.662675

Bhosle NB, Garg A, Fernandes L, Citon P. 2005. Dynamics of amino acids in the conditioning film developed on glass panels immersed in the surface seawaters of Dona Paula Bay. Biofouling. 21:99-107. doi:10.1080/ 08927010500097821

Briand J-F, Barani A, Garnier C, Réhel K, Urvois F, LePoupon C, Bouchez A, Debroas D, Bressy C. 2017. Spatio-temporal variations of marine biofilm communities colonizing artificial substrata including antifouling coatings in contrasted French coastal environments. Microb Ecol. 74:585-598. doi:10.1007/s00248-017-0966-2

Briand J-F, Djeridi I, Jamet D, Coupé S, Bressy C, Molmeret M, Berre BL, Rimet F, Bouchez A, Blache Y. 2012. Pioneer marine biofilms on artificial surfaces including antifouling coatings immersed in two contrasting French Mediterranean coast sites. Biofouling. 28: 453-463. doi:10.1080/08927014.2012.688957

Bulleri F. 2005. Experimental evaluation of early patterns of colonisation of space on rocky shores and seawalls. Mar Environ Res. 60:355-374. doi:10.1016/j.marenvres.2004. 12.002

Charbonnel E, Serre C, Ruitton S, Harmelin J-G, Jensen A. 2002. Effects of increased habitat complexity on fish assemblages associated with large artificial reef units (French Mediterranean coast). ICES J Mar Sci. 59: S208-S213. doi:10.1006/jmsc.2002.1263

Chung KK, Schumacher JF, Sampson EM, Burne RA, Antonelli PJ, Brennan AB. 2007. Impact of engineered surface microtopography on biofilm formation of Staphylococcus aureus. Biointerphases. 2:89-94. [Database] doi:10.1116/1.2751405

Cuadrado-Rica H, Sebaibi N, Boutouil M, Boudart B. 2016. Properties of ordinary concretes incorporating crushed queen scallop shells. Mater Struct. 49:1805-1816. doi:10. 1617/s11527-015-0613-7

Di Pippo F, Ellwood NTW, Guzzon A, Siliato L, Micheletti E, De Philippis R, Albertano PB. 2012. Effect of light and temperature on biomass, photosynthesis and capsular polysaccharides in cultured phototrophic biofilms. J Appl Phycol. 24:211-220. doi:10.1007/s10811-011-9669-0

Doghri I, Rodrigues S, Bazire A, Dufour A, Akbar D, Sopena V, Sablé S, Lanneluc I. 2015. Marine bacteria from the French Atlantic coast displaying high formingbiofilm abilities and different biofilm 3D architectures. BMC Microbiol. 15:231. doi:10.1186/s12866-015-0568-4

Eilers PHC, Peeters JCH. 1988. A model for the relationship between light intensity and the rate of photosynthesis in phytoplankton. Ecol Model. 42:199-215. doi:10. 1016/0304-3800(88)90057-9

Fonsêca-Genevois. V d, Somerfield PJ, Neves MHB, Coutinho R, Moens T. 2006. Colonization and early succession on artificial hard substrata by meiofauna. Mar Biol. 148:1039-1050. doi:10.1007/s00227-005-0145-8

Genty B, Briantais J-M, Baker NR. 1989. The relationship between the quantum yield of photosynthetic electron transport and quenching of chlorophyll fluorescence. 
Biochim Biophys Acta BBA - Gen Subj. 990:87-92. doi: 10.1016/S0304-4165(89)80016-9

Graham PM, Palmer TA, Pollack JB. 2017. Oyster reef restoration: substrate suitability may depend on specific restoration goals. Restor Ecol. 25:459-470. doi:10.1111/rec. 12449

Hanlon N, Firth LB, Knights AM. 2018. Time-dependent effects of orientation, heterogeneity and composition determines benthic biological community recruitment patterns on subtidal artificial structures. Ecol Eng. 122: 219-228. doi:10.1016/j.ecoleng.2018.08.013

Hillebrand H, Worm B, Lotze HK. 2000. Marine microbenthic community structure regulated by nitrogen loading and grazing pressure. Mar Ecol Prog Ser. 204:27-38. doi: 10.3354/meps204027

Hladyz S, Cook RA, Petrie R, Nielsen DL. 2011. Influence of substratum on the variability of benthic biofilm stable isotope signatures: implications for energy flow to a primary consumer. Hydrobiologia. 664:135-146. doi:10. 1007/s10750-010-0593-0

Huang R, Boney AD. 1984. Growth interactions between littoral diatoms and juvenile marine algae. J Exp Mar Biol Ecol. 81:21-45. doi:10.1016/0022-0981(84)90222-3

Hung OS, Thiyagarajan V, Zhang R, Wu RSS, Qian PY. 2007. Attachment of Balanus amphitrite larvae to biofilms originating from contrasting environments. Mar Ecol Prog Ser. 333:229-242. doi:10.3354/meps333229

Hutchinson N, Nagarkar S, Aitchison JC, Williams GA. 2006. Microspatial variation in marine biofilm abundance on intertidal rock surfaces. Aquat Microb Ecol. 42: 187-197. doi:10.3354/ame042187

Jackson AC, Murphy RJ, Underwood AJ. 2013. Biofilms on rocky shores: influences of rockpools, local moisture and temperature. J Exp Mar Biol Ecol. 443:46-55. doi:10. 1016/j.jembe.2013.02.028

Jenkins SR, Arenas F, Arrontes J, Bussell J, Castro J, Coleman RA, Hawkins SJ, Kay S, Martínez B, Oliveros J, et al. 2001. European-scale analysis of seasonal variability in limpet grazing activity and microalgal abundance. Mar Ecol Prog Ser. 211:193-203. doi:10.3354/meps211193

Jensen A, Collins KJ, Lockwood APM. 2000. Artificial reefs in European seas. Dordrecht: Springer Science + Business Media, B. V.; Boston: Kluwer Academic Publishers.

Jesus B, Brotas V, Marani M, Paterson DM. 2005. Spatial dynamics of microphytobenthos determined by PAM fluorescence. Estuar Coast Shelf Sci. 65:30-42. doi:10. 1016/j.ecss.2005.05.005

Jesus B, Mendes CR, Brotas V, Paterson DM. 2006. Effect of sediment type on microphytobenthos vertical distribution: Modelling the productive biomass and improving ground truth measurements. J Exp Mar Biol Ecol. 332: 60-74. doi:10.1016/j.jembe.2005.11.005

Komyakova V, Chamberlain D, Jones GP, Swearer SE. 2019. Assessing the performance of artificial reefs as substitute habitat for temperate reef fishes: Implications for reef design and placement. Sci Total Environ. 668: 139-152. doi:10.1016/j.scitotenv.2019.02.357

Komyakova V, Swearer SE. 2018. Contrasting patterns in habitat selection and recruitment of temperate reef fishes among natural and artificial reefs. Mar Environ Res [Internet]. [accessed 2019 Jan 9]. https://linkinghub.elsevier.com/retrieve/pii/S0141113618305233.
Kromkamp J, Peene J, van RP, Sandee A, Goosen N. 1995. Nutrients, light and primary production by phytoplankton and microphytobenthos in the eutrophic, turbid Westerschelde estuary (the Netherlands). Hydrobiologia. 311:9-19. doi:10.1007/BF00008567

Kromkamp J, Barranguet C, Peene J. 1998. Determination of microphytobenthos PSII quantum efficiency and photosynthetic activity by means of variable chlorophyll fluorescence. Mar Ecol - Prog Ser. [Internet]. [accessed 2019 Nov 4] 162. https://dare.uva.nl/search?identifier= 220f9c9f-be99-48c3-89e0-693ca8818f22.

Langhamer O, Wilhelmsson D. 2009. Colonisation of fish and crabs of wave energy foundations and the effects of manufactured holes - a field experiment. Mar Environ Res. 68:151-157. doi:10.1016/j.marenvres.2009.06.003

Layman CA, Allgeier JE, Montaña CG. 2016. Mechanistic evidence of enhanced production on artificial reefs: a case study in a Bahamian seagrass ecosystem. Ecol Eng. 95:574-579. doi:10.1016/j.ecoleng.2016.06.109

Leite LG, Ciotti ÁM, Christofoletti RA. 2012. Abundance of biofilm on intertidal rocky shores: can trampling by humans be a negative influence? Mar Environ Res. 79: 111-115. doi:10.1016/j.marenvres.2012.06.001

Lejart M. 2009. Etude du processus invasif de Crassostrea gigas en Bretagne: etat des lieux, dynamique et conséquences écologiques [phdthesis] [Internet]. [place unknown]: Université de Bretagne occidentale - Brest; [accessed 2020 Nov 27]. https://tel.archives-ouvertes.fr/tel-00444262.

Ly O, Yoris-Nobile AI, Sebaibi N, Blanco-Fernandez E, Boutouil M, Castro-Fresno D, Hall AE, Herbert RJH, Deboucha W, Reis B, et al. 2020. Optimisation of 3D printed concrete for artificial reefs: biofouling and mechanical analysis. Constr Build Mater. 121649.

Morelle J, Maire O, Richard A, Slimani A, Orvain F. 2021. Contrasted impact of two macrofaunal species (Hediste diversicolor and Scrobicularia plana) on microphytobenthos spatial distribution and photosynthetic activity at microscale. Mar Environ Res. 163:105228. doi:10.1016/j. marenvres.2020.105228

Morris EP, Kromkamp JC. 2003. Influence of temperature on the relationship between oxygen- and fluorescencebased estimates of photosynthetic parameters in a marine benthic diatom (Cylindrotheca closterium). Eur J Phycol. 38:133-142. doi:10.1080/0967026031000085832

Nagarkar S, Williams GA, Subramanian G, Saha SK. 2004. Cyanobacteria-dominated biofilms: a high quality food resource for intertidal grazers. Hydrobiologia. 512:89-95. doi:10.1023/B:HYDR.0000020313.09924.c1

Napoléon C, Fiant L, Raimbault V, Claquin P. 2013. Study of dynamics of phytoplankton and photosynthetic parameters using opportunity ships in the western English Channel. J Mar Syst. 128:146-158. doi:10.1016/j. jmarsys.2013.04.019

Nelder JA, Mead R. 1965. A simplex method for function minimization. Comput J. 7:308-313. doi:10.1093/comjnl/ 7.4.308

NF EN 1097-6. 2014. January. Tests for mechanical and physical properties of aggregates-Part 6: Determination of particle density and water absorption.

NF EN 932-2. 1999. August. Tests for general properties of aggregates- Part 2: Methods for reducing laboratory samples. 
Oh YJ, Lee NR, Jo W, Jung WK, Lim JS. 2009. Effects of substrates on biofilm formation observed by atomic force microscopy. Ultramicroscopy. 109:874-880. doi:10.1016/j. ultramic.2009.03.042

Olivier F, Tremblay R, Bourget E, Rittschof D. 2000. Barnacle settlement: field experiments on the influence of larval supply, tidal level, biofilm quality and age on Balanus amphitrite cyprids. Mar Ecol Prog Ser. 199: 185-204. doi:10.3354/meps199185

Orvain F, de Crignis M, Guizien K, Lefebvre S, Mallet C, Takahashi E, Dupuy C. 2014. Tidal and seasonal effects on the short-term temporal patterns of bacteria, microphytobenthos and exopolymers in natural intertidal biofilms (Brouage, France). J Sea Res. 92:6-18. doi:10.1016/j. seares.2014.02.018

Orvain F, Lefebvre S, Montepini J, Sebire M, Gangnery A, Sylvand B. 2012. Spatial and temporal interaction between sediment and microphytobenthos in a temperate estuarine macro-intertidal bay. Mar Ecol Prog Ser. 458: 53-68. doi:10.3354/meps09698

Patranella A, Kilfoyle K, Pioch S, Spieler RE. 2017. Artificial reefs as juvenile fish habitat in a marina. J Coast Res. 336:1341-1351. doi:10.2112/JCOASTRES-D16-00145.1

Pennesi C, Danovaro R. 2017. Assessing marine environmental status through microphytobenthos assemblages colonizing the Autonomous Reef Monitoring Structures (ARMS) and their potential in coastal marine restoration. Mar Pollut Bull. 125:56-65. doi:10.1016/j.marpolbul.2017. 08.001

Perera-Costa D, Bruque JM, González-Martín ML, GómezGarcía AC, Vadillo-Rodríguez V. 2014. Studying the influence of surface topography on bacterial adhesion using spatially organized microtopographic surface patterns. Langmuir. 30:4633-4641. doi:10.1021/la5001057

Potvin C. 1993. ANOVA: experiments in controlled environments. In: Des Anal Ecol Exp. Scheiner S.M., Gurevitch J. [place unknown]: Oxford University Press; p. 46-68.

R Development Core Team. 2008. R: A language and environment for statistical computing [Internet]. Vienna, Austria: R Foundation for Statistical Computing. http:// www.R-project.org.

Ralph P, Gademann R, Larkum A, Kühl M. 2002. Spatial heterogeneity in active chlorophyll fluorescence and PSII activity of coral tissues. Mar Biol. 141:639-646.

Rijstenbil JW. 2003. Effects of UVB radiation and salt stress on growth, pigments and antioxidative defence of the marine diatom Cylindrotheca closterium. Mar Ecol Prog Ser. 254:37-48. doi:10.3354/meps254037

Roncarati F, Rijstenbil JW, Pistocchi R. 2008. Photosynthetic performance, oxidative damage and antioxidants in Cylindrotheca closterium in response to high irradiance, UVB radiation and salinity. Mar Biol. 153: 965-973. doi:10.1007/s00227-007-0868-9

Salta M, Wharton JA, Blache Y, Stokes KR, Briand J-F. 2013. Marine biofilms on artificial surfaces: structure and dynamics. Environ Microbiol. 15:2879-2893. doi:10.1111/ 1462-2920.12186
Schwarz F, Sculean A, Wieland M, Horn N, Nuesry E, Bube C, Becker J. 2007. Effects of hydrophilicity and microtopography of titanium implant surfaces on initial supragingival plaque biofilm formation. A pilot study. Mund Kiefer Gesichtschir. 11:333-338. doi:10.1007/ s10006-007-0079-z

Sekar R, Venugopalan VP, Satpathy KK, Nair KVK, Rao VNR. 2004. Laboratory studies on adhesion of microalgae to hard substrates. Hydrobiologia. 512:109-116. doi: 10.1023/B:HYDR.0000020315.40349.38

Sokołowski A, Ziółkowska M, Balazy P, Plichta I, Kukliński P, Mudrak-Cegiołka S. 2017. Recruitment pattern of benthic fauna on artificial substrates in brackish low-diversity system (the Baltic Sea). Hydrobiologia. 784:125-141. doi:10.1007/s10750-016-2862-z

Souche J-C, Saout GL, Salgues M, Pioch S. 2016. Effets de bétons bio-actifs sur la colonisation marine en environnement méditerranéen. Matér Tech. 104:504. doi:10. 1051/mattech/2016033

Stock W. 2019. Assessing the suitability of Imaging-PAM fluorometry for monitoring growth of benthic diatoms. J Exp Mar Biol Ecol. 7.

Strickland JDH, Parsons TR. 1968. A practical handbook of seawater analysis. [place unknown]: Queen's Printer.

Tamburri MN, Luckenbach MW, Breitburg DL, Bonniwell SM. 2008. Settlement of Crassostrea ariakensis larvae: effects of substrate, biofilms, sediment and adult chemical cues. J Shellfish Res. 27:601-608. doi:10.2983/07308000(2008)27[601:SOCALE2.0.CO;2]

Thompson RC, Moschella PS, Jenkins SR, Norton TA, Hawkins SJ. 2005. Differences in photosynthetic marine biofilms between sheltered and moderately exposed rocky shores. Mar Ecol Prog Ser. 296:53-63. doi:10.3354/ meps 296053

Thompson RC, Norton TA, Hawkins SJ. 2004. Physical stress and biological control regulate the producer-consumer balance in intertidal biofilms. Ecology. 85: 1372-1382. doi:10.1890/03-0279

Underwood AJ. 1984. Microalgal food and the growth of the intertidal gastropods Nerita atramentosa Reeve and Bembicium nanum (Lamarck) at four heights on a shore. J Exp Mar Biol Ecol. 79:277-291. doi:10.1016/00220981(84)90201-6

Vivier B, Dauvin J-C, Navon M, Rusig A-M, Mussio I, Orvain F, Boutouil M, Claquin P. 2021. Marine artificial reefs, a meta-analysis of their design, objectives and effectiveness. Glob Ecol Conserv. 27:e01538. doi:10.1016/j.gecco. 2021.e01538

Webb WL, Newton M, Starr D. 1974. Carbon dioxide exchange of Alnus rubra : A mathematical model. Oecologia. 17:281-291. doi:10.1007/BF00345747

Weerman EJ, van de Koppel J, Eppinga MB, Montserrat F, Liu Q-X, Herman PMJ. 2010. Spatial self-organization on intertidal mudflats through biophysical stress divergence. Am Nat. 176:E15-32. doi:10.1086/652991

Whalan S, Webster NS. 2014. Sponge larval settlement cues: the role of microbial biofilms in a warming ocean. Sci Rep. 4:4072. doi:10.1038/srep04072 